\title{
Neke spoznaje o zbrinjavanju i zdravstvenoj skrbi diece s Kozare u prihvatilištima 1942. godine
}

Igor Vukić

Društvo za istraživanje trostrukog logora Jasenovac

Ilija Kuzman

Medicinski fakultet Sveučilišta u Zagrebu

Akademija medicinskih znanosti Hrvatske

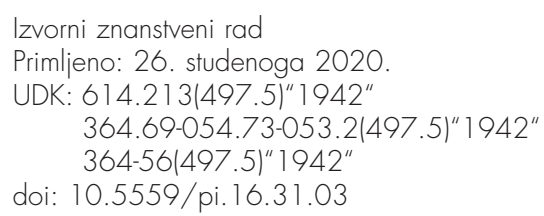

Nakon ofenzive hrvatske i njemačke vojske na području planine Kozare u ljeto 1942. godine nastao je zbjeg $s$ velikim brojem izgladnjele i bolesne djece. Kad je slomljen otpor partizanskih snaga, vece skupine djece iz zbjega privremeno su smještane u nekoliko prihvatnih centara (logor Stara Gradiška, sabirališta u selima Mlaka, Jablanac, Uštica i drugdje), a zatim su, bez prethodnih priprema, prevezene u različita prihvatilišta s ciljem pružanja pomoći i zdravstvene skrbi te su potom udomljavana u obitelji. $U$ organizaciji zbrinjavanja djece presudna je bila uloga države, a iz dostupnih dokumenata jasno se razabire da je djeci u prihvatilištima uz smještaj i prehranu pružana i odgovarajuća zdravstvena skrb, odnosno da djeca nisu bila diskriminirana i zanemarivana. Osnovna je namjera ovoga rada, korištenjem izvornog arhivskog gradiva i izjava sudionika događaja (sudski zapisnici), pokazati da su djeca s Kozare i Potkozarja 1942. godine u prihvatilištima u Jastrebarskom, Sisku i Zagrebu imala odgovarajuću opću i zdravstvenu skrb u skladu s mogućnostima tadašnje medicine u zadanim ratnim okolnostima.

Naime, sve do danas u različitim medijima postoji cijeli niz stavova o namjernom izgladnjivanju, trovanju i mučenju te djece. Ovdje želimo istaknuti da su to proizvoljni i činjenično neutemeljeni navodi koje su plasirale jugoslavenske komunističke vlasti odmah nakon završetka Drugoga svjetskog rata, ali i pojedine društvene, političke pa i znanstvene strukture. Stoga, u duhu znanstvenih spoznaja, mislimo da su nazivi dječji ili ustaški logori neprimjereni te da bi bilo uputnije koristiti nazive prihvatilišta ili sabirališta za djecu, pa i privremene bolnice za djecu.

Ključne riječi: Drugi svjetski rat, Nezavisna Država Hrvatska, Dječje prihvatilište Jastrebarsko, Dječje prihvatilište Sisak, Zavod za odgoj gluhonijeme djece, Dječji dom na Josipovcu, zarazne bolesti 


\section{Uvod}

Danas gotovo historiografski fenomen — pitanje prihvata, smještaja i skrbi o djeci s Kozare i Potkozarja u prihvatilištima što ih je organizirala vlast Nezavisne Države Hrvatske (NDH) u ljeto 1942. godine, nakon vojnih operacija na planini Kozari, zaslužuje detaljnu i teorijski preciznu obradu, lišenu ideoloških i navijačkih natruha.

$\mathrm{Na}$ temelju dostupnih podataka o organizaciji i zbrinjavanju djece te pružanju opće i medicinske skrbi u dva najveća prihvatilišta, u Sisku i Jastrebarskom te u prihvatilištima u Zagrebu (Zavod za odgoj gluhonijeme djece i Dječji dom na Josipovcu), pokušat ćemo dokazati da su ta djeca imala odgovarajuću zdravstvenu skrb, sukladnu ratnim uvjetima izbjegličkih valova izgladnjelog pučanstva, u higijenski zapuštenim prilikama opće bijede i siromaštva s proširenom ušljivosti te nedostatkom medicinskog osoblja, uz epidemije brojnih zaraznih bolesti. U to vrijeme nisu postojali antibiotici niti današnja mogućnost prevencije bolesti cijepljenjem. Prema dostupnim dokumentima i drugim izvorima djeca u prihvatilištima nisu bila zanemarivana, a pogotovo ne diskriminirana, u pružanju zdravstvene skrbi u odnosu na opću populaciju, odnosno drugu djecu.

U radu smo koristili izvorne arhivske dokumente vlasti NDH (ministarstava zdravstva, udružbe i unutarnjih poslova, zatim nadležnih uprava za skrb poput glavnih ravnateljstava za zdravstvo i udružbu te dokumente mjesnih, općinskih i župskih tijela i oružničkih i vojnih postrojbi), potom zapisnike sa sudskih postupaka vođenih poslije rata i poslijeratne izvještaje koje su podnosili sudionici događaja (primjerice, pred komisijama za utvrđivanje ratnih zločina okupatora i njegovih pomagača). Osim toga, služili smo se memoarskim zapisima i dnevnicima, novinskim izvještajima te objavljenim knjigama, zbornicima dokumenata i drugim člancima koji se odnose na ta zbivanja. ${ }^{1}$

Odmah nakon završetka rata 1945. godine u službenu je historiografiju plasirano i sve do danas se održalo uvjerenje o potpunoj nebrizi i izostanku svake zdravstvene skrbi za ovu djecu, a nerijetko su iznošeni stavovi o njihovu namjernom izgladnjivanju, trovanju i mučenju. ${ }^{2}$

1 Neki od tih izvora jesu: Dnevnik Diane Budisavljević, Zagreb, 2003; Ćiril PETEŠıć, Dječji dom Jastrebarsko, Zagreb, 1990; četiri knjige zbirke dokumenata Koncentracioni logor Jasenovac, dokumenta, uredio Antun Miletić (prve tri knjige Jasenovac, 1986., četvrta Jagodina, 2007.); Nataša MATAUŠIĆ, Diana Budisavljević, prešućena heroina Drugog svjetskog rata, Zagreb, 2020; neobjavljeni rukopis Narcise Lengel-Krizman "Spašavanje djece" (u posjedu autora); dnevne novine Hrvatski narod, Vjesnik, Plavi vjesnik, Borba i tjednik Arena. 


\section{Vojno-politička situacija i ofenziva na Kozaru}

Ubrzo nakon osnutka NDH na prostorima naseljenim većinskim srpskim, odnosno pravoslavnim stanovništvom, a osobito na području Bosne i Hercegovine dolazi do neposluha i pružanja otpora novim vlastima. Prve oružane akcije bilježe se već u travnju i svibnju 1941. godine, a prva pobuna većih razmjera događa se u lipnju u Hercegovini (tzv. Lipanjski ustanak). ${ }^{3}$ Novi val ustanaka rasplamsava se potkraj srpnja i početkom kolovoza 1941. godine, kada se bilježe jače oružane akcije i na području Kozare i Potkozarja. Iako

2 Navodi o zlostavljanju i ubijanju djece u logorima i prihvatilištima pojavljuju se u zapisnicima poslijeratnih komisija za utvrđivanje ratnih zločina okupatora i njegovih pomagača te u zapisnicima sa sudskih procesa (primjerice, u procesu vođenom protiv $\mathrm{dr}$. Antuna Najžara, upravitelja prihvatilišta u Sisku). Zatim u knjigama i zbornicima, poput: Voja JOVANOVIĆ, Deca i rat. Jugoslavija 1941. - 1945., Beograd, 1962; Dragoje LUKIĆ, Kozarsko djetinjstvo, 1976; ISTI, Rat i djeca Kozare, Beograd, 1979; Jurica KÖRBLER i Petar STANIVUKOVIĆ, Deca u logorima smrti, Beograd, 1986; u novinskim feljtonima poput Jana KOCH, "Sjećanje na akciju spašavanja kozaračke djece iz jasenovačkog logora", Plavi vjesnik, Zagreb, listopad 1971. — siječanj 1972. Novinski feljtoni o kozaračkoj djeci objavljivani su gotovo u svim dnevnim novinama u SFRJ, u svim republikama. Redovito su održavani okrugli stolovi (u Jasenovcu, Banjoj Luci, Beogradu) i priređivane izložbe o djeci u logorima u Staroj Gradiški i Jasenovcu te prihvatilištima (spomenuti Dragoje Lukić i sam je bio dijete iz te skupine; rođen 1928., bio je u prihvatilištu u Jastrebarskom, a priredio je niz izložbi u Jastrebarskom, Beogradu, Jasenovcu i na spomen-području Mrakovica na Kozari, prema: Dragan LUKIĆ, Bili su samo deca, Laktaši, 2006.). Prihvatilišta se na takvim skupovima i izložbama redovito nazivaju "ustaški logori za djecu“. U Hrvatskoj se u novije vrijeme ponavljanjem optužbi iz poratnog vremena bavi u svojim izdanjima Savez antifašističkih boraca, primjerice, Ivan FUMIĆ, Djeca - Žrtve ustaškog režima, Zagreb, 2011. Propagandni pristup stradavanju djece u ratu bio je prisutan i u dokumentarnim i igranim filmovima, primjerice u filmu Lordana Zafranovića Krv i pepeo Jasenovca iz 1983. godine. Najnoviji primjer je Dara iz Jasenovca, igrani film snimljen 2019. u Srbiji, redatelja Predraga Antonijevića i scenaristice Nataše Drakulić. S druge strane, umjereniji i faktografski pristup ovoj temi može se zamijetiti u novinskom serijalu "Arena traži vaše najmilije koji je sedamdesetih godina u tjedniku Arena vodio novinar Marino Zurl, tragajući za djecom izgubljenom u ratnom vihoru koristeći i kartoteku koju je vodila Diana Budisavljević. Dio potrage opisao je u knjizi: Marino ZURL, Tri jablana, Zagreb, 1978. U novije vrijeme vaŽan doprinos rasvjetljavanju sudbine kozaračke djece dao je dr. Nikica Barić, radom u Časopisu Pilar: "Kozara 1942, sudbina civila, zarobljenika i djece", br. 2, rujan 2017, te osvrtom na film Dnevnik Diane Budisavljević autorice Dane Budisavljević (snimljen 2019. godine), objavljenom u Časopisu za suvremenu povijest, br. 3, u studenom 2020. Sudbinom kozaračke djece bavila se i hrvatska povjesničarka dr. Narcisa Lengel Krizman. Objavila je niz članaka u različitim časopisima (npr. "Akcija spasavanja kozarske i druge djece iz ustaških logora ", Zbornik radova, Prijedor, 1980. i članak istog naslova u zborniku Deca, rat i revolucija, Beograd, 1981.). Nakon 1991. godine dr. Narcisa Lengel Krizman ponovno je pregledala izvore i uz kritički pristup revidirala neke svoje i tuđe zaključke u radu pod nazivom "Spašavanje djece". Iako je postojala namjera da se taj rad objavi, to se nije dogodilo pa je do sada ostao u rukopisu.

3 Više o tim zbivanjima u: Amir OBHOĐAŠ, Zima 1941./1942, vojne operacije u istočnoj Bosni, Zagreb, 2020., 27-114. 
je na tom području bilo i četničkih grupa, organizatori pobune bili su pretežno članovi Komunističke partije Jugoslavije, a pobunjeničke postrojbe imale su partizanska obilježja. Gotovo svi partizani, uz tek pokoju iznimku među zapovjednim kadrom, bili su srpske narodnosti i pravoslavne vjere. ${ }^{4}$

U proljeće 1942. godine partizanski pokret je ojačao, njegove postrojbe upadale su u slabo branjena sela i manja gradska naselja te izvodile zasjede na prometnicama. U tim mjestima su uništavane oružničke postaje, škole i druge javne zgrade. U svibnju 1942. partizani su zauzeli Prijedor i rudnik Ljubiju, vrlo važan za opskrbu njemačke vojne industrije željeznom rudačom. ${ }^{5}$ Svojim djelovanjem zaprijetili su i sigurnosti važnih prometnica, među ostalim i željezničkoj pruzi Zagreb - Banja Luka. Odmah nakon zauzimanja Prijedora, njemačko zapovjedništvo za Jugoistok zajedno s hrvatskim postrojbama isplaniralo je vojnu akciju slamanja partizanske skupine na planini Kozari i okolici. U svibnju je oformljena borbena skupina Zapadna Bosna, pod zapovijedanjem njemačkog generala Friedricha Stahla, a potom je cijeli prostor Kozare i Potkozarja opkoljen sa svih strana. ${ }^{6}$

Već ranije su partizanski odredi sa sobom u planinske baze povlačili i civile, članove svojih obitelji i stanovnike sela koji su se bojali odmazde nakon partizanskih napada na punktove formalne vlasti. I prije masovnih povlačenja prema Kozari i samih vojnih operacija, bilo je civila, među njima i djece, koji su u tom brdovitom predjelu nekoliko mjeseci proveli u teškim životnim uvjetima, spavajući u kolibama i zemunicama. ${ }^{7}$

Situacija u kojoj se našlo civilno stanovništvo postaje još teža nakon početka vojne akcije protiv pobunjenih partizana. Vojni pothvat započeo je 10. lipnja 1942. godine, a završio je tridesetak dana kasnije. ${ }^{8}$ U zbjegovima na planini našle su se tisuće civila s nedovoljnim zalihama hrane. Već tijekom borbenih operacija, našavši se u teškim stambenim i higijenskim prilikama, mnogi civili prihvatili su pozive koje su im upućivale hrvatske vlasti putem letaka bacanih iz zrakoplova. Letcima su ih pozivali na predaju i izlazak u susret vojnicima te im jamčile život.9 Nakon predaje ili zarobljavanja, na kra-

\footnotetext{
${ }^{4}$ Više o tim zbivanjima u: Dušan D. SAMARDŽIJA, Bosanskodubičko područje u NOR-u i socijalističkoj revoluciji 1941-1945., Bosanska Dubica, 1984., 53-113.

5 Mira KOLAR-DIMITRIJEVIĆ, "Rudnik željezne rude Ljubija za vrijeme okupacije“, u zborniku Kozara u NOB i socijalističkoj revoluciji, Prijedor, 1981., 363-377.

6 Nikica BARIĆ, "Kozara 1942, sudbina civila, zarobljenika i djece“, n. dj., 53-56; Dušan D. SAMARDŽJA, nav. dj., 197.

7 Dušan D. SAMARDŽIJA, nav. dj., 199.

8 Nikica BARIĆ, "Kozara 1942...", 59; Dušan D. SAMARDŽIJA, nav. dj., 199-208.

9 Nikica BARIĆ, "Kozara 1942...", 55, 66-67; Dušan D. SAMARDŽIJA, nav. dj., 209; izjava sudionice događaja Dušanke Radulović dana autoru 14. lipnja 2017. godine u Donjoj Gradini.
} 
ju vojnih operacija, civili su upućivani u prihvatne centre koji su se nalazili kod Bosanske Dubice, u selu Uštici kod Jasenovca, u Prijedoru, u Novskoj i drugdje. Nakon završetka vojnih djelovanja, osim s Kozare iseljavano je stanovništvo i iz nekih sela naseljenih pravoslavnim stanovništvom na širem prostoru, primjerice, južno od Bosanske Gradiške. Stanovnici iz tih mjesta i zarobljenici upućivani su preko Bosanske i Stare Gradiške u sela Mlaku i Jablanac, koja se nalaze na lijevoj obali Save, između Jasenovca i Stare Gradiške. ${ }^{10}$

Sredinom srpnja 1942. godine te prihvatne centre posjetio je ministar zdravstva u Hrvatskoj državnoj vladi dr. Ivo Petrić. ${ }^{11}$ Nakon povratka u Zagreb dao je izjavu dnevniku Hrvatski narod, objavljenu 23. srpnja. "Država je već prije našeg dolaska tamo uputila veliku količinu hrane, uputila 20 liečnika, 15 sestara, 5 razkužitelja, liekove, zavojno i razkužno tvorivo, serume i cjepiva. Zdravstveni zavod u Banjoj Luci i postrojbe Crvenog križa pojačale su u tom području svoju djelatnost, da pomognu prebjege i da im uzmognu nakon njihove katastrofe u Kozari sačuvati i spasiti živote", izjavio je uz ostalo dr. Ivo Petrić. ${ }^{12}$

Ministar je dodao da su u prihvatnim centrima u Mlaki, Jablancu i Prijedoru organizirane ambulante i prihvatne bolnice te da se obavlja raskuživanje i dezinsekcija od velikog broja ušiju kod izbjeglica. "Nije to mali posao, jer je zamazanost i ušljivost kod sviju dosegla svoj najveći stupanj. Osim toga svi se postepeno cijepe protiv tifusa i griže [...]. Sve ovo iziskuje najveće napore, jer je ogromna masa zaušena, zagađena i bolestna stigla nakon partizanskog uništenja naglo, u kratkom roku od nekoliko dana."13

Moguće je da je posjet dr. Petrića bio odgovor na dopise što su stizali s terena s upozorenjima o teškoj humanitarnoj situaciji. U dopisu upućenom tajništvu Ministarstva unutarnjih poslova, službenik s terena (potpis nečitak) javio je 13. srpnja da se "pitanje prihvata i evakuacije pučanstva razvija na našu sramotu. Na sva moja upozorenja brzoglasom, do sad u Dubicu nije stiglo ništa osim tri mlada liječnika, bez sredstava. Potrebna je najažurnija me-

10 Antun MILETIĆ, Koncentracioni logor Jasenovac 1941-1945, Dokumenta, knjiga III., Beograd-Jasenovac, 1986., dok. br. 85, str. 200, izvješce Mihajla Komunickog, izaslanika Ministarstva udružbe NDH kod opunomoćenika Vlade NDH u Banjoj Luci.

11 Dr. Ivo Petrić (1897.-1968.), liječnik, do 1941. ravnatelj Zarazne bolnice u Zagrebu. Ministar zdravstva od travnja 1941. do listopada 1942. godine, u svibnju 1945. povlači se u Austriju, Italiju i 1948. emigrira u Argentinu. Vidi Tko je tko u NDH, Zagreb, 1997. 12 Hrvatski narod, br. 483, 23. srpnja 1942., str. 3, pod naslovom "Zauzimanje i briga Hrvatske državne vlade oko partizanskih prebjega sa Kozare . Dr. Petrić je to područje posjetio s ministrom vanjskih poslova dr. Mladenom Lorkovićem i pratnjom.

13 Isto. 
đuministarska organizacija. Nijemci prigovaraju i traže odgovore tko je kriv za to“. 14

Oružnička zapovjedništva tih su dana javljala i o pojavi pjegavog tifusa u selima u okolici Kozare. Primjerice u kotaru Prijedor, gdje je u selima Komičani, Dera, Trnjani, Kozaruša i Brđani u općini Kozarac sanitetska služba ustanovila 64 slučaja pjegavog tifusa, od kojeg su četiri osobe umrle. Oružnička postaja Kozarac izvijestila je da je kotarska vlast poduzela sve potrebne mjere kako bi se suzbilo širenje bolesti. ${ }^{15}$

Širenje bolesti suzbijalo se i na drugim mjestima. Ministarstvo zdravstva obratilo se 14. srpnja 1942. godine Kotarskoj oblasti u Novskoj sa zapovijedi da "depedikulaciju i ostale zdravstvene mjere protiv zaraznih bolesti u logoru Novska preuzme kotarski liečnik dr. Marijan Derkos i općinski liečnik dr. Mijo Škrljac iz Novske، ${ }^{16}$ Po nalogu Ministarstva zdravstva iz Zagreba, tog istog dana, 14. srpnja, u selo Jablanac, koje se nalazi nekoliko kilometara nizvodno Savom od Jasenovca, otputovali su liječnici dr. Leopold Auf, dr. Herbert Klemenčić i dr. Slavko Župan. Njihov je zadatak bio da ondje uspostave privremenu stanicu za sprječavanje zaraznih bolesti. Potkraj srpnja, nakon povratka u Zagreb, u izvješću o svome radu naveli su da su "od 15. do 17. ciepili po prvi put 2000 ljudi a osim toga smo potrebnima pružili liečničku pomoć i liečničke savjete. Dne 17. o. mj. došla su još 2 liečnika t.j. doktor Silobrčić Petar i dr. Vadkov Nikola sa 2 dobrovoljne sestre pomoćnice Crvenog križa. Nastavilo se ciepljenjem i zdravstvenim radom, tako da smo do 25. pociepili prvi i drugi put (vakcinacija). Uz svoj rad u Jablancu dne 22. VII. ciepili smo čitavo pučanstvo u Mlaki po drugi put. (U oba mjesta oko 10.000 ljudi.) Za vrieme našega boravka u Jablancu umrlo je po logorima i kućama preko 30, što odraslih, što diece. Porodilo se je 21 diete, gravidnih 102 , pobačaj $1 .{ }^{17}$

Liječnici su također utvrdili da su civili s Kozare, koje su partizani ostavili pri povlačenju, jako izgladnjeli, a smrtnost među malodobnom djecom je visoka. "Najveći postotak je gastrointestinalnih poremećenja, svrab u velikom postotku sa vrlo čestim ekcemima i piodermijama. Ustanovili smo oko 100

\footnotetext{
${ }^{14}$ Hrvatski državni arhiv (HDA) 487, Ministarstvo oružanih snaga Nezavisne Države Hrvatske (NDH), mikrofilm D-2178, snimka br. 555.

15 HDA 226, Ministarstvo zdravstva i udružbe NDH (dalje: HDA 226), Glavno ravnateljstvo za zdravstvo, br. 48267-Z-1942, izvješće primljeno 29. srpnja 1942., a podnio ga je pukovnik Obertynski.

16 Nikica BARIĆ, "Kozara 1942..", 71.

17 HDA 226, Glavno ravnateljstvo za zdravstvo, 48152-Z-1942. U izvornom dokumentu Jablanac se naziva Jablanovo, ali je iz dokumenta jasno da se radi o Jablancu kod Jasenovca.
} 
slučajeva malarije sa kliničkom slikom. Slučajeva pjegavog tifusa i trbušnog tifusa, dizenterije ili drugih zaraznih bolesti nije se moglo do sada ustanoviti. Kod 10-12 slučajeva flegmena i panaricija pružili smo liečničku pomoć,, navedeno je u izvještaju. ${ }^{18}$

Dr. Auf i njegovi kolege napisali su i da je u prihvatnom centru bilo nemoguće provesti dezinfekciju i dezinsekciju jer nije bilo potrebne opreme ni prikladnih prostorija. "Pučanstvo u logoru je pod vedrim nebom i izloženo nepogodama vremena a ono malo što je pod krovom, stanuje prenatrpano. Pošto smo sve pregledali i pociepili (prvi i drugi put) to smo prema tome savjesno izvršili povjerenu nam dužnost. Moramo spomenuti da nijesmo imali dovoljnu količinu liekova, usprkos ponovnog traženja, da smo radi pomanjkanja joda i alkohola morali upotrebiti privatni alkohol i benzin te i štrcala jednoga od nas, a da ne govorimo o tome da za broj od oko 10.000 ljudi nije bilo ni za 10\% dovoljna količina liekova. Najviše pomanjkanje je bilo tannalbina i karbo animalis (lijekovi za liječenje proljeva — nap. a.). Trebalo je još kinina u manjoj mjeri. Malo je bilo liekova proti svrabu. Zavojnog materijala je bilo relativno dovoljno a nije posve dovoljno bilo masti za rane. Vrlo nam je falilo joda i alkohola“, stoji u izvještaju.19

Mnogo informacija o stanju na tom području može se doznati i iz poslijeratnog ispitivanja dr. Nikole Vadkova pred službenicima Odjeljenja zaštite naroda (OZN). ${ }^{20}$ Vadkov je ispričao kako ga je 16. srpnja 1942. godine u svoj ured pozvao dr. Mladen Petras ${ }^{21}$, pročelnik Odjela za zdravstvo Ministarstva zdravstva. Uz Vadkova pozvano je još nekoliko liječnika. Objašnjeno im je da je pred njima važan zadatak i da svi moraju sudjelovati. Dr. Vadkov je dobio nalog da s dr. Petrom Silobrčićem ide u okolicu Jasenovca kako bi pomagali izbjeglicama s Kozare i Potkozarja. Prema iskazu dr. Vadkova, u Jasenovcu ih je dočekao dr. Miljenko Gjivoje i uputio u Mlaku (selo pored Jablanca, udaljeno devet kilometara jugoistočno od Jasenovca) i Jablanac. ${ }^{22}$

Dr. Vadkov također navodi da su ondje već bili kirurg dr. Župan, rendgenolog dr. Auf, ortoped dr. Klemenčić te dvije bolničarke Hrvatskoga Crvenog križa, Cindrić i Henigman. Prisjetio se kako je tih dana vladala velika žega, a nije bilo mjesta za skrivanje od sunca. Hrana je bila slaba, iako su se-

\footnotetext{
18 Isto.

19 Isto.

20 HDA 1561, Služba državne sigurnosti RSUP SRH, 015.7.11, izjava Nikole Vadkova od 1. studenoga 1945., RZ0070725-RZ0070740

21 Dr. Mladen Petras (1905._-1974.), liječnik, ortoped, od 1941. do 1942. predstojnik Odjela za zdravstvo pri Ministarstvu zdravstva, a potom pročelnik Odjela za zdravstvo kod Glavnog ravnateljstva za zdravstvo u Ministarstvu unutarnjih poslova. Poslije rata nastavlja raditi u nekoliko zagrebačkih bolnica. Vidi Tko je tko u NDH.
} 
ljaci poveli sa sobom stoku, ali nisu je htjeli klati i pripremati za jelo. Nadali su se, vjerojatno, da će se uskoro moći vratiti u svoje domove i povesti sa sobom svoju vrijednu imovinu. 23

Veliki broj ljudi na malom prostoru, u lošim higijenskim uvjetima, stvorio je podlogu za širenje bolesti. Dr. Vadkov opisuje da su ljudi patili od krvavog proljeva, a svakog je dana umiralo nekoliko žena i djece. On i njegovi suradnici tražili su da im se iz Zagreba dostavi dodatna pošiljka lijekova. Rekao je i da je razgovarao i s Hinkom Piccilijem, jednim od voditelja radne službe obližnjeg logora u Jasenovcu. Doznao je da je za izbjeglice stigao pun vagon kukuruza i pola vagona soli. No Piccili je to skrenuo u logor za potrebe zatočenika. Dr. Vadkov je ipak uspio dogovoriti da se kukuruz proslijedi u Mlaku. Piccili nije htio dopustiti da se kukuruz samelje, jer je za to mlin navodno morao imati posebnu dozvolu. Dr. Vadkov je tako preuzeo vagon kukuruza u klipu. "Sada se po čitave dane i noći čula tutnjava batova kojima su tukli kukuruz da bi se lakše skuhao. ${ }^{24}$

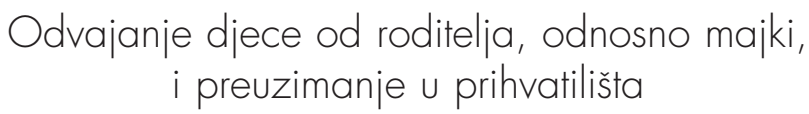

Nešto prije ili usporedno s vojnim operacijama, vlasti NDH i predstavnici Trećeg Reicha postigli su sporazum o upućivanju zarobljenika i dijela iseljenog pravoslavnog stanovništva kao radnika u tvornice i na poljoprivredne radove u Njemačku. ${ }^{25}$ Prema dogovoru, djeca do 14 godina trebaju "ostati na brigu hrvatskoj državi«. ${ }^{26}$ Prema različitim podatcima, u prihvatnim centrima ostalo je oko 7000 djece čiji su roditelji upućeni na rad u Njemačku. Pojavio se ozbiljan problem smještaja tako velikog broja djece bez prethodnih priprema i plana zbrinjavanja. Zato je prema odluci samog poglavnika Ante Pavelića tu djecu trebalo smjestiti u dječja prihvatilišta u Sisku, Jastrebarskom, Zagrebu i drugdje. ${ }^{27}$

\footnotetext{
${ }^{22}$ HDA 1561, Služba državne sigurnosti RSUP SRH, 015.7.1, izjava Nikole Vadkova od 1. studenoga 1945., RZ0070725-RZ0070740

23 Isto.

${ }^{24}$ Isto.

${ }^{25}$ Nikica BARIĆ, "Kozara 1942...", 63.

26 Antun MILETIĆ, nav. dj., knjiga I., dok. br. 137, str. 357 i bilješka na istoj stranici njemačkog natporučnika Schmidt-Zabierowa o posjetu Staroj Gradiški kamo je otišao s dr. Petersenom, opunomoćenikom za prikupljanje radne snage

27 ISTI, knjiga IV., dok. 36, 109-110; po svemu sudeći nije postojao raniji plan da se djecu odvaja od roditelja nego se tome pristupilo ad hoc, u dogovorima u hodu, onako kako su ta djeca s roditeljima pristizala u prihvatne centre. Ispočetka su i djeca upućivana u Njemačku s roditeljima, ali nakon što su njemački liječnici u tranzitnim cen-
} 
Od 24. lipnja do 4. srpnja 1942. godine iz Uštice i Stare Gradiške u Dječji dom za izbjegličku djecu u Gornjoj Rijeci kraj Križevaca dovedeno je 325 djece. Nakon što je ondje izbila zaraza pjegavim tifusom, dom je rasformiran. Dvadesetak djece udomljeno je u obiteljima oko Varaždina, a neka su smještena u varaždinsku bolnicu. U Zagreb je prebačeno 257 djece od kojih je 52 smješteno u Zaraznu bolnicu. Ondje je umrlo 20 (16 dječaka i 4 djevojčice), a 32 je izliječeno. Skupina od 147 djece odvezena je u dom u Jastrebarsko i ondje stavljena u posebnu oformljenu karantenu u dijelu franjevačkog samostana. I odatle su djeca u manjim skupinama ili pojedinačno upućivana u zagrebačke bolnice na liječenje. Od posljedica pjegavca umrlo je ukupno 90 djece iz doma u Gornjoj Rijeci ( 55 u tom domu, ostali u bolnicama). ${ }^{28}$

Iz Stare Gradiške upućen je 11. srpnja 1942. godine transport sa 650 djece u Zagreb i Jastrebarsko. Slijedili su transporti 13. i 14. srpnja (oko 700 djece). ${ }^{29}$ U prihvatnim centrima, odnosno, raskužnim postajama kod Glavnog kolodvora u Zagrebu i drugdje organizirana je dezinfekcija i kupanje pridošle djece koliko je to bilo moguće zbog njihove dobi i zdravstvenog stanja. U Zagrebu su djeca privremeno smještana u Zavod za odgoj gluhonijeme djece, u Jeronimsku dvoranu te Staklenik (prostor kod katedrale koji je ustupio nadbiskup Alojzije Stepinac). U neke od tih prostora već su tada dolazili građani Zagreba i preuzimali djecu na obiteljsku skrb. ${ }^{30}$

Ministarstvo udružbe naložilo je 16. srpnja liječniku dr. Ivi Karađoli da ode u Mlaku i preuzme 200 djece koju su onamo dovedena iz Dubice. Naloženo mu je da svu djecu mlađu od dvije godine uputi u Zagreb i o tome obavijesti Ministarstvo. 31

U međuvremenu je zbog velikog broja ljudi u prihvatnim centrima počelo ponestajati hrane. Ministarstvo zdravstva poslalo je 23. srpnja brzojav Oskaru Turini, opunomoćeniku Vlade NDH sa sjedištem u Banjoj Luci.32 U brzojavu je prenesena obavijest Crvenoga križa da "prebjezi u Mlaki i Jablan-

trima u Mariboru i Linzu ustanovili da je mnogo djece u tim prvim transportima bolesno, transporti su vraćani u Hrvatsku. Vidi Nataša MATAUŠIĆ, nav. dj., 99.

28 Narcisa LENGEL-KRIZMAN, "Spašavanje djece", neobjavljeni rukopis (u posjedu autora), 31-35; Ćiril PETEŠIĆ, nav. dj., 26.

29 HDA 1722, Antifašistički front žena (AFŽ), kut. 8/45, Popis ratom postradale djece.

30 Dnevnik Diane Budisavljevic, HDA, Zagreb, 2003., 98, 104, 107.

31 HDA 226, Glavno ravnateljstvo za zdravstvo, br. 45.447-Z-1942

32 Dr. Oskar Turina od 13. lipnja 1942. do 22. studenoga 1942. bio je na dužnosti "obćeg opunomoćenika Vlade Nezavisne Države Hrvatske" sa sjedištem u Banjoj Luci. Uz ostalo, bio je zadužen za organiziranje prihvata i opskrbe izbjeglica. 
cu još uvijek nemaju dovoljnu prehranu. Ministarstvo zdravstva nije u stanju voditi o tome računa. Izvolite stvar izviditi i shodno odrediti.،33

Potkraj srpnja Ministarstvo udružbe osnovalo je komisiju na čijem je čelu bio nadzornik iz toga ministarstva Franjo Perše. Zadatak komisije bio je organizirati nastavak preuzimanja djece iz sabirnih centara u Jablancu, Mlaki i drugih. U skladu s time, Hrvatski Crveni križ je 28. srpnja svojoj dobrovoljnoj bolničarki Dragici Habazin izdao putni nalog u kojem je navedeno: „Prema saopćenju Ministarstva udružbe od 27. srpnja o.g. ima se organizirati preuzimanje i prijevoz djece iz sabirnih logora Jasenovac, Mlaka i Uštica, koje dužnosti ima izvršiti posebna komisija na čelu sa g. Franjom Perše, nadzornikom Ministarstva udružbe. Na traženje spomenutog Ministarstva izvolite $\mathrm{s}$ navedenom komisijom otputovati u spomenute sabirne logore u svrhu pružanja pomoći kod preuzimanja i prijevoza djece. Kad na licu mjesta upoznate prilike, izvolite najbržim putem saopćiti koliko bi još sestara trebalo odaslati tamo, da budu od pomoći kod preuzimanja prijevoza djece. 34

Zapovjedništvo sabirnih logora u Jasenovcu izdalo je 28. srpnja propusnicu Dragici Habazin kojom joj dopušta slobodan pristup i prolaz kroz logor do Mlake i Jablanca, radi obavljanja službenih poslova. Propusnica je vrijedila deset dana. 35 Put iz Jasenovca do sela Košutarica (iz kojeg se dalje išlo cestom uz Savu do Mlake i Jablanca) vodio je izravno kroz logor Jasenovac. Tako su sve liječničke ekipe i transporti djece i odraslih prolazili cestom koja je vodila kroz logor.

Ravnateljstvo Hrvatskih državnih željeznica Zagreb primilo je 29. srpnja 1942. godine sljedeći dopis Odjela društvovnog osiguranja, zaštite i skrbi Ministarstva udružbe: „U sabirnim logorima u Jablancu, Mlaki i Uštici imade još oko 2.500 djece koja se po nalogu Poglavnika imadu preuzeti u držav. dječju zaštitu Ministarstva udružbe, kao i djeca iz sabirnih logora u St. Gradiški, koja su već preuzeta. Pomenuta djeca smjestiti će se u privatnim nastambama u Jastrebarskom. Savezno s time moli se naslov, da osigura prievoz ove djece u partijama od po 600-800 i to sa postaja Raić, odnosno Jasenovac. Pri dolazku u Zagreb moraju se djeca prije polazka u Jastrebarsko razkužiti. Polazak prvog i idućih transporta javiti će se brzoglasno naslovu čim komisija preuzme djecu. Moli se vozni red vlakova udesiti tako, da isti stižu u Zagreb rano ujutro, a poslije podne oko $16 \mathrm{~s}$. odlaze za Jastrebarsko. 36

\footnotetext{
33 HDA 226, Glavno ravnateljstvo za zdravstvo, br. 46.936-Z-1942

${ }^{34}$ Antun MILETIĆ, n. dj., knjiga IV., dok. br. 34, str. 105; Dnevnik Diane Budisavljević, 82.

35 Antun MILETIĆ, n. dj., knjiga IV., dok. Br. 33, str. 104; Dnevnik Diane Budisavljević, 83.
} 
U dokumentu se nalazi formulacija "po nalogu Poglavnika". Takvu formulaciju mogli su upotrebljavati isključivo uredi samog Poglavnika (Poglavnikov vojni ured, Županstvo pri Poglavniku), a ostale vlasti mogle su je koristiti samo kada im je Ante Pavelić osobno, usmeno ili u pisanom obliku dao ovlast ili nalog da je mogu upotrijebiti u vezi s rješavanjem određenog pitanja. 37

Nakon povratka sa zadatka na koji je upućen, nadzornik Franjo Perše je 7. kolovoza 1942. godine podnio izvješće Ministarstvu udružbe u kojem je naveo: "29. srpnja o. g. uputio sam se u Jasenovac, a odavle u logore u Uštici, Mlaki i Jablancu. U Uštici nije bilo djece, jer su odpremljena u druge logore. U Mlaki bilo je, kao i u Jablancu oko 5.683 djece. Razloživši narodu svrhu našeg dolaska počeo sam s popisom djece i za prvi prevoz sabrao 850, a za drugi 967 i za treći 1250 djece. Prvi prevoz izvršen je 30. i 31. srpnja. Drugi 2. i 3. kolovoza, a treći 4., 5. i 6. kolovoza. Prvi je prevoz upućen u Zagreb, a drugi i treći u Sisak. Kod svakog prevoza pomagale su sestre $\mathrm{Hr}-$ vatskog crvenog križa, koje su vodile i brigu oko prehrane djece na putu. [...] Roditeljima obrazložena je korist te dječje kolonizacije, pa se nije vršila nikakova sila, već je dobrovoljnom predajom u sva tri prevoza preuzeto 3.067 djece. U sva tri prevoza nije bilo smrtnih slučajeva, prem bilo je mnogo slučajeva posvemašne izgladnjelosti. Prevoz vršio se običnim seoskim kolima, jer po onom uskom derutnom putu ne bi bilo moguće to izvršiti drugim prevoznim sredstvima. Svaki put je trajao od Mlake do Jasenovca po 3 do 4 sata, a od Jablanca 6 sati. 38

S putnim nalogom Hrvatskoga Crvenog križa i propusnicom Ustaške obrane u Mlaku je 29. srpnja 1942. godine iz Zagreba stigla i volonterka Diana Budisavljević39 sa suradnicima i nekoliko sestara Crvenoga križa radi preuzimanja djece. Govorili su majkama da daju djecu u Zagreb, da će ondje djeci biti lijepo jer će biti smještena u dječjim domovima, bolje nego u vlastitoj kući. Uskoro su majke počele prilaziti stolovima na kojima se obavljalo popisivanje. "Sestre su donijele i poslastice za djecu, kuhale čaj, tješile ih", is-

36 Antun MILETIĆ, n. dj., knjiga IV., dok. br. 36, str. 109.

37 Barić, "Kozara 1942...", 100.

38 Isto.

39 Diana Budisavljević, rođ. Obexer (1891.-1978.), Austrijanka rođena u Innsbrucku, udana za Julija Budisavljevića (1882.-1981.), kirurga, predstojnika Kirurške klinike Medicinskog fakulteta Sveučilišta u Zagrebu. Diana Budisavljević sudjelovala je u pomaganju zatočenicima pravoslavne vjere (slanje paketa u logor Lobor-grad) i u zbrinjavanju pravoslavne djece nakon vojne akcije na Kozari. Osobito je važna njezina uloga u izradi i vođenju kartoteke zbrinute i udomljene djece. Vidi Dnevnik Diane Budisavljević, Zagreb, 2003; Nataša MATAUŠIĆ, n. dj. 
pričao je liječnik Nikola Vadkov. ${ }^{40} \mathrm{U}$ prikupljanju djece i stavljanju u kola koja su ih vozila do jasenovačke željezničke postaje pomagali su i mladi ustaški vojnici iz logorske stražarske postrojbe, zapisala je u dnevnik Diana Budisavljević. 41

Iz Jablanca je 800 djece odvezeno u Jastrebarsko 31. srpnja 1942. godine. Sljedeća skupina od 106 djece iz Mlake odvezena je u Zagreb i smještena u dom na Josipovcu. Zatim 3. kolovoza iz Mlake kreće 800 djece u Sisak, gdje počinje $s$ radom dječje prihvatilište. U to prihvatilište 4 . kolovoza stiže 650 djece iz Stare Gradiške, a 5. kolovoza još 1200 djece iz Mlake. ${ }^{42}$

Određena medicinska pomoć djeci pružana je i u logoru u Staroj Gradiški. Organizirao ju je liječnik Viktor Budicki, jedan od zatočenika u logoru. Naime, u Staru Gradišku su još od svibnja 1942. godine dovođeni civili s Korduna, obuhvaćeni protupartizanskim akcijama koje su vodile snage NDH na tom području. Među njima je bio i velik broj djece sa zaraznim bolestima. Dr. Budicki je najteže oboljele odvajao i smještao u improviziranu "dječju bolnicu«s oskudnim raspoloživim sredstvima za pomoć. 43

Zbog spomenutog dogovora s Nijemcima, kojima je stalno trebala radna snaga, muškarci i žene upućivani su na rad u Njemačku. Ispočetka su s njima odlazila i djeca. No, događalo se da bi u Mariboru ili Linzu, gdje su njemački liječnici pregledavali pridošlice, bilo ustanovljeno da u transportima ima znatan broj bolesnih, pa su transporti vraćani natrag u Hrvatsku. ${ }_{44}$ Vjerojatno su zbog toga njemački predstavnici zatražili da se djecu više ne šalje, nego da ostanu "na brizi hrvatskoj državi«. 45

O proširenosti zaraznih bolesti u privremenim prihvatilištima vrlo zorno govori podatak iz transporta s 336 osoba koji je 29. lipnja 1942. godine vraćen iz Linza te su svi smješteni u Zavod za odgoj gluhonijeme djece u Ilici 83 u Zagrebu. Među njima je bilo 38 muške djece, 83 ženske djece i 215 žena. Liječnici su kod njih ustanovili 160 slučajeva svraba, 128 slučajeva dizenterije, 48 slučajeva ospica (morbili), devet slučajeva upale pluća, četiri slučaja pjegavog i tri slučaja trbušnog tifusa. Odmah je u Bolnicu za zarazne bo-

\footnotetext{
40 Izjava Nikole Vadkova u HDA 1561, SDS RSUP SRH, 015.7.11, RZ0070725

41 „Velika djeca idu poslušno, ali malene treba nositi. Morali smo ih tražiti u brdima jastuka. U tome je naročito savjestan bio jedan mladi ustaša koji je bio zdvojan, jer se bojao da ćemo neko malo djete previdjeti pa će pokisnuti." Dnevnik Diane Budisavljević, 88.

${ }^{42} \mathrm{HDA}, 1722$, AFŽ, kut. 8/45, Popis ratom postradale djece.

43 Ilija JAKOVLJEVIĆ, Konclogor na Savi, Zagreb, 1999., 100.

44 Nataša MATAUŠÍ́, n. dj., 100.

45 Antun Miletic, n. dj., knjiga I, dok. br. 137, str. 357, bilješka o posjetu Staroj Gradiški.
} 
lesti poslano 16 bolesnika, a ostali su se liječili u Zavodu. Vraćeni iz transporta bili su uglavnom pravoslavci iz sela u okolici Gline, Hrvatske Dubice i Kostajnice, Vojnića, Jasenovca, Novske i Cetingrada. U tom se trenutku u Zavodu nalazilo 658 štićenika, a od toga 435 djece i 223 odrasle osobe. Liječničku službu u Zavodu obavljala je dr. Božena Radovinović, uz pripomoć liječnika dr. Branka i Nine Dragišić, dr. Talera i dr. Franje Pernuša. ${ }^{46}$

\section{Civilni izbjeglički val katolika i muslimana 1941.-1942. godine}

Ovdje valja spomenuti i ratne događaje iz 1941. godine koji su rezultirali prihvatom izbjeglica u Staroj Gradiški i Zagrebu. Naime, nakon rasplamsavanja pobune protiv hrvatske države u ljeto te godine, pred napadima i zločinima odmetnika (tada, uglavnom četnika) veliki je broj civila katolika i muslimana iz područja sjeverne Dalmacije i jugozapadne Bosne tražio spas u sjevernim dijelovima Hrvatske. Primjerice, oko 1250 izbjeglica iz Bihaćkog kotara smješteno je u kaznionicu Stara Gradiška, koja tada još nije služila kao logor, nego je u njoj bilo mjesta jer je već započelo preseljavanje dotadašnjih kažnjenika na druga mjesta. Među izbjeglicama bili su, primjerice, žene i djece iz postradalog sela Boričevca. ${ }^{47}$ Ubrzo su se među djecom proširile različite zarazne bolesti pa su prebacivana u bolnicu u Novoj Gradiški na liječenje. Tih dana djeca iz hrvatskih zbjegova (iz katoličkih i muslimanskih obitelji) stizala su i u Zagreb. Smještali su ih privremeno u Dom na Josipovcu (današnja Nazorova ulica) te u Zavod za odgoj gluhonijeme djece. Ondje su ih pregledale dr. Olga Bošnjaković i dr. Mara Brčić. Prema njihovu nalazu, djeca su bila "slabo uhranjena, mnoga su preplašena, a veliki dio je tako zapušten, boluje od svraba i sličnih kožnih bolesti, te će trebati dugo vremena da se ta djeca oporave uz veoma pomnu njegu“. 48

Bolesti su harale i među izbjeglicama islamske vjere što su spas potražili u bijegu pred četnicima iz okolice Foče. Prema brzojavu upućenom 13. ožujka iz kotara Gacko na više adresa, među ostalima, i Ministarstvu udružbe, "u kotaru Gacko vlada glad i bolest, više smrtnih slučajeva od gladi među izbjeglicama iz Foče kojih ima u mjestu oko 500. Hrana ne dolazi peti mjesec, pošta već treći mjesec, činovnici bez plaće i sredstava za život četvrti mjesec « 49 O teškom stanju katoličkih i muslimanskih izbjeglica kojih je u

\footnotetext{
46 HDA 226, Glavno ravnateljstvo za udružbu, 51769-I-2, izvještaj br. 627, s potpisom ravnatelja zavoda Ljudevita Šafarića, poslan iz Zavoda za odgoj gluhonijeme djece 6. srpnja.

47 Dossier Boričevac, ur. Josip Pavičić, Zagreb, 2012., 435.

48 Isto, 431.

49 HDA 226, Glavno ravnateljstvo za udružbu, 18435-I/1.
} 
ljeto i jesen 1942. u Banjoj Luci, Sanskom Mostu, Bosanskoj Dubici i drugdje bilo u jednakom broju kao i onih pravoslavnih s Kozare, govori izvještaj Higijenskog zavoda iz Banje Luke od 15. studenoga 1942. godine. Opisuje se smještaj izbjeglica među kojima ima onih pristiglih iz Hercegovine: "Svi izbjeglice skoro bez iznimke žive u nepovoljnim društvovnim i zdravstvenim prilikama. Hrana je veoma slaba i nedostatna, postoji najveća oskudica u odjeći i rublju tako da se često nailazi na djecu koja osim košulje ništa drugo na sebi nemaju, novčana pomoć je mala i neredovita. Veliki broj majki dojilja nije u stanju dojiti dijete, jer im je mlijeko u dojkama presahnulo zbog nedovoljne prehrane. Djeca su mahom slabunjava i rahitična. Njihov je pomor veoma visok." 50

\section{Dječje prihvatilište Jastrebarsko}

Uoči prijevoza djece u Jastrebarsko, gdje je već postojao dječji dom, 51 taj je grad obišao sanitarni inspektor Ministarstva zdravstva. Bilo je to 16. srpnja 1942. godine. ${ }^{52}$ Ministarstvo vanjskih poslova NDH 18. srpnja 1942. godine obratilo se Višem zapovjedništvu talijanskih oružanih snaga "Slovenija-Dalmacija u Sušaku, nadležnom za talijanske postrojbe u NDH. U dopisu je objašnjeno da u Jastrebarskom postoje barake koje je upotrebljavala talijanska vojska, a u kojima su trenutačno smještena mnogobrojna djeca "nastradala uslied djelovanja partizana». Upravo tih dana u Jastrebarsko su došli talijan-

\footnotetext{
50 Higijenski zavod Banja Luka, Taj. br. 99, izvještaj podnio dr. Ivan Grujić, upravitelj Higijenskog zavoda i zdravstveni izvjestitelj kod opunomoćenika Vlade NDH Oskara Turine.
}

51 Od 1939. godine u Jastrebarskom je postojao Dječji dom za poodrasle dječake, koji su vodile časne sestre iz reda Kćeri Božje ljubavi (sjedište im je bilo u Sarajevu). Također 1939. godine u Jastrebarsko je premješten i dom, odnosno sirotište iz Osijeka, kojim su upravljale slovenske sestre milosrdnice, "usmiljenke» iz reda Kćeri kršćanske ljubavi sv. Vinka Paulskog. Godine 1941. dom za dječake je zatvoren, a sirotište se vratilo u Osijek. U Jastrebarskom je 1941. formiran novi dom, Dječji dom za djevojčice, namijenjen djevojčicama koje su ostale bez roditelja u četničkim napadima u Bosni. Za upraviteljicu doma imenovana je č. s. Pulherija (Anka) Barta, inače svastika dr. Mile Budaka, književnika i ministra u vladama NDH. Tom domu 1942. godine pridodano je prihvatilište za djecu s Kozare; vidi Ćiril PETEŠIĆ, n. dj., 11-13; Zdenko VUKOVIĆ, Istine i laži o Jastrebarskom, 29-30.

52 Nikica BARIĆ, "Kozara 1942...", 99; HDA, 226, Glavno ravnateljstvo za zdravstvo, broj 46.886-Z-1942. Sanitarni inspektor ustanovio je da zdenac u Franjevačkom samostanu ne osigurava dovoljno vode pa je već 17. srpnja, zanemarujući formalnosti, "zbog žurbe i više sile započelo kopanje novog zdenca, a provedeno je i raskuživanje postojećeg. Također je ustanovljeno da ciglana u obližnjem mjestu Reki nema odgovarajuću opskrbu vodom. Kako bi se osiguralo dovoljno vode za piće, pranje i kuhanje na tom mjestu, trebalo je izvršiti radove na uređivanju obližnjeg izvora. Ministarstvo zdravstva je dopisom od 22. srpnja obavijestilo o tome Ministarstvo udružbe, zatraživši da se žurno osiguraju potrebna financijska sredstva za izvođenje opisanih radova. 
ski predstavnici, s namjerom da barake razmontiraju i odnesu drvnu građu. Zato su vlasti u Zagrebu zatražile od Talijana da barake, barem u tom razdoblju, ostanu na raspolaganja za smještaj djece. Talijani su odgovorili da se slažu s navedenim zahtjevom, odnosno da barake u Jastrebarskom prepuštaju mjesnim hrvatskim vlastima. 53

Prihvatilište u Jastrebarskom organizirano je u nastambama, odnosno barakama kod Franjevačkog samostana, zatim u barakama u selu Reka (kod tamošnje ciglane), dok je bolnica za najteže bolesnu djecu organizirana u starom gradu Erdödijevih u središtu Jastrebarskog. U prvom transportu 11. srpnja 1942. godine u Jastrebarsko je dovezeno 850 djece, 250 djevojčica smješteno je u barake kod starog grada, a u tri barake kod franjevačkog samostana smješteno je 600 dječaka. 54

O zdravstvenom stanju djece koja su stigla u Jastrebarsko svjedočio je dr. Branko Dragišić55 pred organima Zemaljske komisije za utvrđivanje zločina 10. prosinca 1945. godine. Odmah po dolasku djece dr. Dragišić je preuzeo vođenje improvizirane bolnice u Jastrebarskom. Prema njegovoj izjavi, djeca su stigla s teškim atrofijama uslijed gladi i s napadnim crvenilom sluznice usta, mekoga nepca i ždrijela. "Mnogo djece imalo je infekciozne bolesti, našli smo nekoliko slučaja akutnog pjegavca, vrlo mnogo ospica, neobično mnogo difterije nosa i ždrijela te vodenih kozica«, rekao je dr. Dragišić.

Znatan dio djece bolovao je i od teške toksičke griže (dizenterija), a sva su djeca bolovala od po nekoliko bolesti: npr. kombinacija tifus - dizenterija - ospice - difterija nosa i ždrijela - ulcerozne stomatitide najtežega stupnja i mnogo edema na nogama od gladi. Dr. Dragišić je u ispitivanju naveo da je bilo oko 400 slučajeva dizenterije, oko 300 slučajeva ospica s upalama pluća, oko 200 slučajeva trbušnog tifusa, mnogo skorbuta s ispadanjem zubi i sekvestriranjem čeljusti. Navodi i brojne avitaminoze te na stotine ulceroznih stomatitida s dvadesetak noma, s potpunom destrukcijom obraza. Difterija nosa i ždrijela bilo je oko 200, varičela (vodenih kozica) i zaušnjaka (pertussis epidemica) oko 100. "Šarlaha je bilo malo, tuberkuloze koliko se moglo ustanoviti bez rendgenskog pregleda nije bilo mnogo. Svraba i raznih gnojnih infekcija na koži neobično mnogo. Veliki dio djece pokazao je

\footnotetext{
53 Nikica BARIĆ, "Kozara 1942...", 99.

54 Ćiril PETEŠIĆ, n. dj., 24.

55 Dr. Branko Dragišić (1895.-1947.), pedijatar, profesor na Medicinskom fakultetu, poslije rata ravnatelj Dječje klinike na Šalati u Zagrebu. Sin pravoslavnog svećenika iz Dvora na Uni. Od listopada 1941. do puštanja na slobodu u proljeće 1942. bio je interniran u logoru u Staroj Gradiški zbog pripadanja grupi zagrebačkih masona (bio je član lože Pravednost od 1929. godine). Vidi Ćiril PETEŠIĆ, n. dj., 23; brošura Memento 1941/1942 o povijesti slobodnih zidara, Zagreb, 2011
} 
znakove preboljenog pjegavca, koji su vjerojatno preboljeli još u logoru Gradiška, s ispadanjem kose, gnojnim procesima na koži, atrofijama najtežeg stepena i s greškama na srčanom mišiću, apscesima... Takove stepene skorbuta i teških avitaminoza sumnjam da je ikada imao prilike da vidi jedan liječnik kod djece», izjavio je dr. Dragišić. Dodao je kako je bilo djece „koja su kod najmanjeg napora kod ustajanja iz kreveta, da vrše nuždu, naglo umirala kao snoplje od opće tjelesne iscrpljenosti i slabosti."56

Stanje u Jastrebarskom opisao je i Kamilo Bresler, savjetnik u Odsjeku za obitelj i djecu u Ministarstvu udružbe ${ }^{57}$ u pismu upućenom 12. srpnja 1942. godine dr. Niktopolionu Černozubovu, epidemiologu, voditelju epidemiološkog odjela pri Hrvatskom higijenskom zavodu58. Zatražio je od njega da u Jastrebarsko pošalje opremu i lijekove za pristigle bolesnike. Novac neće biti problem, istaknuo je Bresler. "Od bolesti koje smo danas mogli primijetiti pored desperatnog stanja ishranjenosti skorbut, griža, ogroman broj ospica i upale pluća, difterija, jedan sumnjiv pjegavac", napisao je Bresler.

Dr. Dragišić je organizirao bolnicu u Jastrebarskom, kako je izjavio, "prema propisima jedne bolnice za djecu s kapacitetom od 110 kreveta". Bila je razdijeljena na odjele — za tifus, dizenteriju, difteriju itd. 59

Budući da su stizala i nova djeca, odnosno bolesnici, liječnici u Jastrebarskom bili su prisiljeni organizirati nove bolničke odjele. Radili su to u dogovoru s Breslerom, koji je prema Dragišićevim informacijama u Jastrebarsko poslao i dodatne liječnike: dr. Glumca iz bolnice Sestara milosrdnica u

56 Ćiril PETEŠIĆ, n. dj., str. 25.

57 Kamilo Bresler (ili Brössler, kako prezime glasi u izvornim dokumentima) (Varcar Vakuf 1901. — Krk 1967.), osnovnu školu i gimnaziju završio je u Sarajevu, učiteljsku školu u Petrinji, Filozofski fakultet u Zagrebu (skupina pedagoško-psihologijskih predmeta). Radio je u Crvenom križu (1929.), Školi narodnog zdravlja, Državnoj školskoj poliklinici (1936.). U NDH radi u Ministarstvu udružbe, kao savjetnik u Odjelu za zaštitu majke i djeteta. Poslije rata bio je načelnik Odjela socijalne zaštite i skrbi u Ministarstvu socijalne politike Narodne vlade Hrvatske (1946.). Bio je osnivač i nastavnik Više škole za socijalne radnike u Zagrebu (1954.). Vidi Ćiril PETEŠIĆ, n. dj., 21-22.

58 Dr. Niktopolion Černozubov (Njižni Novgorod 1890. — Beograd 1967.), epidemiolog, profesor na Medicinskom fakultetu, autor udžbenika (Epidemiologija, izdanja 1941. i 1973.). Diplomirao je u Sankt Peterburgu 1918., a nakon bijega iz Rusije 1921. devet godina radi u Sandžaku (Novi Pazar i okolica). U Zagrebu je od 1930.; voditelj je epidemiološkog odjela u Higijenskom zavodu do 1943. kada odlazi u partizane. Od 1944. bio je šef Higijensko-epidemiološkog odsjeka pri Vrhovnom štabu. Do 1952. bio je na dužnosti glavnog epidemiologa JNA i načelnik Higijenskog zavoda Vojnomedicinske akademije. Predavao je na Medicinskom fakultetu u Beogradu i ravnao Institutom za epidemiologiju Medicinskog fakulteta, Vidi Hrvatski biografski leksikon, Leksikografski zavod Miroslav Krleža, Zagreb, 2009.—2020, mrežno izdanje, https://hbl.lzmk.hr/ clanak.aspx?id=4006 (pristupljeno 31. ožujka 2021.)

59 Ćiril PETEŠIĆ, n. dj., 26. 
Zagrebu te dvije liječnice časne sestre reda sv. Vinka koje su promovirane u Beogradu. Bile su to specijalistice pedijatrije, rodom iz Slovenije, s. Imelda Potočnik i s. Kristina Bele. Zbog nedostatka medicinskog osoblja Bresler je tih dana poslao jednu časnu sestru u Beograd kako bi pozvala nekoliko pripadnica reda sv. Vinka, koje su ondje imale samostan, da dođu pomagati u Jastrebarsko. Uz dvije časne sestre pedijatrice, odazvalo se još osam redovnica koje su iz Srbije doputovale u Jastrebarsko.60

Časne sestre su dobile nadzor nad barakama u Reki, gdje je bilo oko 1000 djece. Dr. Dragišić i njegova supruga, također liječnica dr. Nina Dragišić, vrlo često su poslijepodne odlazili i provjeravali stanje u tim nastambama. Dr. Dragišić je izjavio da je bolnica ondje organizirana u najljepšoj, suhoj baraci, i to za oboljele od ospica i upale pluća izazvane ospicama.

$\mathrm{Na}$ dvorištu je uređen prostor u obliku sjenice za liječenje upala pluća od ospica na svježem zraku. U drugoj baraci postojao je odjel za dizenteriju, za difteriju nosa i ždrijela, te ambulanta. Oboljeli s upalom pluća dobivali su dnevno injekcije za srce, a oni s dizenterijom dijetu prema mogućnostima, ribane jabuke, rižinu sluz itd.

"Kad je bolnica bila organizirana i kad nam je uspjelo da spomenutim mjerama smanjimo smrtnost djece, javljeno mi je da ustaše raspuštaju logor u Gornjoj Rijeci kod Križevaca, jer se tamo pojavio pjegavac među djecom. I tu djecu su uputili jednostavno u Jastrebarsko. Sada je bio za nas problem, da već u sređene medicinske prilike primimo oko 280 djece u inkubaciji“, prisjetio se dr. Dragišić. U konačnici je u Jastrebarsko stiglo 147 djece iz Gornje Rijeke. ${ }^{61}$ Dr. Dragišić je stoga predložio Bresleru da se isprazni franjevački samostan u kojem se tada nalazilo samo nekoliko redovnika i da se djeca tamo smjeste uz strogu karantenu. Zdravstvena skrb za tu skupinu povjerena je dr. Karlu Weissmanu. ${ }^{62}$

Kroz bolnicu u starom gradu u centru Jastrebarskog prošlo je oko 300 malih bolesnika. Pojedini bolesnici prebacivani su u zagrebačke bolnice na liječenje kad bi trebalo obaviti neke kirurške zahvate ili su bila potrebna neka laboratorijska, rendgenska i druga ispitivanja. U Zaraznu bolnicu bilo je upućeno 48 djece (umrlo desetero), a na Dječju kliniku (118, umrlo 35).63

\footnotetext{
60 Isto.

61 Narcisa LENGEL-KRIZMAN, n. dj., 34.

62 Dr. Karlo Weissman bio je Židov iz Osijeka, internist, u Osijeku je imao vlastiti sanatorij. Upraviteljici Jastrebarskog č. s. Pulheriji preporučila ga je nadstojnica osječkog dječjeg doma, č. s. Veronika Iglič; vidi Ćiril PETEŠIĆ, n. dj., 26-27; Zdenko VUKOVIĆ, n. dj., 59 .
} 
Ukupno je kroz prihvatilište Jastrebarsko prošlo 3400 djece. Umrlo je 444 djece (oko 13 posto). ${ }^{64}$ Smrtnost je bila najveća u djece iz prvog transporta (12. srpnja 1942.), odnosno u prvom mjesecu boravka u prihvatilištu, a kasnije ustrojem bolnice, organiziranjem zdravstvene skrbi i poboljšanjem prehrane mortalitet se bitno smanjio (tablica 1).

Tablica 1. Kronološki pregled smrtnosti djece u prihvatilištu u Jastrebarskom 1942. godine 65

\begin{tabular}{lrr}
\hline Razdoblie & $\begin{array}{r}\text { Broj } \\
\text { umrle djece }\end{array}$ & $\begin{array}{r}\text { Prosječni dnevni } \\
\text { broj umrlih }\end{array}$ \\
\hline 12. - 31. srpnia & 153 & 7,65 \\
\hline 1. kolovoza - 30. rujna & 216 & 3,54 \\
\hline 1. - 31. listopada & 67 & 2,16 \\
\hline 1. studenoga - 31. prosinca & 6 & 0,1 \\
\hline nakon 1. siječnja 1943. & 2 & - \\
\hline Ukupno & 444 & - \\
\hline
\end{tabular}

\section{Dječje prihvatilište u Sisku}

U Sisku je prihvat djece nakon završetka vojnih operacija na Kozari organiziran u nekoliko zgrada u užem i širem centru grada. I ovdje je odabir prostora vodio Kamilo Bresler, predstavnik Ministarstva udružbe. Za povjerenika Ministarstva u Sisku imenovan je učitelj Ante Dumbović, a za zdravstvenog voditelja i upravitelja cijelog prihvatilišta dr. Anton Najžar.66 Djeca su bila smještena na ovim lokacijama: u Samostanu sestara sv. Vinka, u Sokolani, u

63 Ćiril PETEŠIĆ, n. dj., 100. Dr. Dragišić u svojem izvješću navodi da je dječje prihvatilište u Jastrebarskom za djecu poslije operacije na Kozari postojalo četiri i pol mjeseca, od 12. srpnja do 1. studenoga 1942. godine. U tom je razdoblju, prema njegovim podatcima, umrlo 444 djece.

${ }^{64}$ Isto, 26-28, 96-102, izjava dr. Branka Dragišića u ispitivanju pred Zemaljskom komisijom za utvrđivanje zločina okupatora i njegovih pomagača u Zagrebu 10. prosinca 1945., ZKRZ GUZ, 4676/45. Petešić navodi i podatak da je umrlo 452 djece, prema izvještaju Odjela socijalne zaštite djece i mladeži pri Ministarstvu socijalne politike NR Hrvatske iz siječnja 1947., što daje sličan postotak umrlih.

65 Isto, 26-27, 100; podatci iz izjave dr. Branka Dragišića u ispitivanju pred Zemaljskom komisijom za utvrđivanje zločina okupatora i njegovih pomagača 10. prosinca 1945. ZKRZ GUZ 4676/45.

66 Dr. Anton Najžar (Obrež kod Ptuja 1899. — okolica Siska 1947.) završio je Medicinski fakultet u Zagrebu, od 1941. bio je ravnatelj Školske poliklinike u Sisku. Bio je upravitelj dječjeg prihvatilišta i liječnik u sabirnom logoru u Sisku za prikupljanje radne snage za Njemačku (1942.—1945.). Poslije rata u prvostupanjskom postupku osuđen je na dvadeset godina zatvora, a nakon žalbe tužitelja, unatoč brojnim svjedocima u njegovu korist, osuđen je na smrt i strijeljan. Vidi Državni arhiv u Sisku, Zbirka sudskih predmeta političkih procesa, dr. Anton Najžar, STUP 46/46, 560; HDA 1722, AFŽ, kut 8/40. 
skladištu Solane Reiss te u školi u Novom Sisku. Određeni broj najteže bolesne djece smješten je i u sisačku bolnicu. ${ }^{67}$

Kotarska komisija za utvrđivanje ratnih zločina pri Narodnom odboru u Sisku napravila je poslije rata elaborat o dječjem prihvatilištu u Sisku, u kojem su opisane prostorije za smještaj djece te nabrojeno osoblje koje se o njima brinulo. Navedena su imena liječnika - dr. Anton Najžar, dr. Leopold Auf, dr. Lazar Margulies, dr. Ivan Špicer i dr. Briški i pomoćnog osoblja, od kuharica koje su pripremale hranu do pomoćnih radnika koji su cijepali drva. 68

Prema tom elaboratu djeca su prvo prolazila kroz dezinfekcijsku postaju u kupalištu Teslić, gdje su ih kupali i šišali. U zgradi Sokolane liječnicima je pomagalo tridesetak žena, koje je organizirala Julija Šepić, predsjednica (tabornica) Ženske loze ustaškog pokreta iz Siska. ${ }^{69} \mathrm{U}$ prizemlju Sokolane bila je centralna kuhinja u kojoj je radilo desetak žena. Istražitelji iz komisije precizno su naveli imena svih žena koje su pomagale u svakoj prostoriji Sokolane. Iz elaborata je vidljivo da je pored ulaza bila ambulanta. Na prvom katu bila je i manja soba koja je služila kao mrtvačnica. ${ }^{70}$

Na sličan način opisana je i zgrada škole u Novom Sisku. Ondje je ambulanta bila na prvom katu. Postojala je "soba za dojenčad" i dvije-tri sobe za smještaj starije djece. Osim medicinskih sestara koje su u prihvatilište došle s liječnicima, s kojima su i do tada radile u njihovim ordinacijama, u pomaganju djeci sudjelovale su i sestre pomoćnice Crvenoga križa, zatim redovnice dominikanke koje su došle iz Zagreba te redovnice iz Samostana sv. Vinka. Također je iz obližnjeg sabirnog logora Staklana (koji je služio za prikupljanje radne snage za Njemačku) dovedena skupina žena koje su pomagale u zbrinjavanju pristigle djece. ${ }^{71}$

67 HDA 1722, AFŽ, kut 8/9, 40.

68 Mrtvozornik je bio David Eckstein (Egić), prijevoz leševa obavljao je Tomo Ozić, grobar se zvao Franjo Videc, cjepač drva bio je Janko Biškupović: HDA 1722, AFŽ, kut. $8 / 40$.

69 Julija Šepić odlikovana je Redom za zasluge III. stupnja "za osobito požrtvovan rad oko opskrbljivanja napuštene djece s Kozare“. Odlikovanje joj je dodijelio poglavnik Ante Pavelić 1944. godine, u HDA 306, Zemaljska komisija za utvrđivanje ratnih zločina - Glavni urudžbeni zapisnik (ZKRZ-GUZ), kutija 136, 8563-/V-1946. Nakon rata osuđena je na deset godina zatvora zbog "aktivnog ustaštva". Kao suradnicu na zbrinjavanju djece spominje ju u svojem dnevniku i Diana Budisavljević.

70 HDA 1722, AFŽ, kut 8/40.

71 Isto. Časne sestre koje su pomagale oko djece zvale su se Partenija Grubišić, Mirna Mastanjević i Marija Alma Lesić; vidi sudski postupak protiv dr. Antuna Najžara, Zbirka sudskih predmeta političkih procesa, Državni arhiv Sisak, STUP 46/46. 
Unatoč svim njihovim naporima, u sisačkom je prihvatilištu od 7. do 31. kolovoza umrlo 515 djece. Dr. Anton Najžar podnio je 7. rujna 1942. godine izvještaj o stanju u Dječjem prihvatilištu Sisak Ministarstvu udružbe i Ministarstvu zdravstva. U prilogu izvještaja je i tablica s brojem umrle djece po danima i pojedinim lokalitetima prihvatilišta od 7. do 31. kolovoza 1942. U tom razdoblju ukupno je umrlo 515 djece (prema zapisima A. Dumbovića - umrlo ih je nešto više, 537). Nije naveden ukupan broj djece koja su tada bila smještena u prihvatilištu, a nisu precizno navedeni ni uzroci, odnosno dijagnoze bolesti umrle djece. ${ }^{72}$

Najviša smrtnost bila je u Samostanu (209 umrlih) gdje su bila smještena dojenčad i mala djeca, a glavnim razlogom navodi se pothranjenost s probavnim tegobama i crijevnim infekcijama. Smrtnost je bila vrlo visoka unatoč liječničkoj skrbi i odgovarajućoj dijetalnoj prehrani. Stoji napomena da su sva djeca bila cijepljena protiv dizenterije. ${ }^{73}$

U objektu Sokolana umrlo je 141 dijete, a tu je bio smješten i najveći broj djece u ekstremno lošim uvjetima jedne nedovršene zgrade bez prozora. Uz loše higijenske prilike, razlogom velike smrtnosti navode se zarazne bolesti - dizenterija, ospice i zaušnjaci. ${ }^{74}$

Škola u Novom Sisku s vodovodom i kanalizacijom od 22. kolovoza funkcionira kao bolnica za najteže bolesnike koji su premještani iz Sokolane. Ondje su isprva bila smještena najzdravija djeca, ali se premještanjem bolesne djece od 22. kolovoza bilježi i velika smrtnost s ukupno 151 umrlim djetetom do kraja mjeseca. ${ }^{75}$

Dr. Najžar u izvješću opisuje kako je veći pomor u Samostanu nastajao nakon šest dana od dolaska djece, koja su prethodno oduzeta od majki, kada je došao do izražaja drukčiji način prehrane te su uslijedile razne promjene u probavnom traktu. "Uz to su naknadno došle i razne zaraze (Colli eventualno dizenterija, a nisu isključeni ni zaraznici iz grupe paratifusa). Uz to se mora spomenuti, da su djeca bila potpuno gola bez potrebnih pokrivača, te se mora računati da je veliki procenat pomora djece išao na račun te golotinje tj. hladnoće, kojoj mala djece ne mogu odolijevati. Djeca su spavala na slami eventualno zamotana u kakve krpice", napisao je dr. Najžar. On dalje tvrdi da je liječnička služba kod djece bila na potrebnoj visini pa su "sva dje-

\footnotetext{
72 HDA 226, Glavno ravnateljstvo za zdravstvo, br. 61832-I-1942, Državna dječja poliklinika Sisak br. 405/42; usp. Izvještaj Ante Dumbovića u HDA, 1722, AFŽ, kut. 8/ 9, Popis pomrle djece iz 1942. godine, 1-1152

73 HDA 226, Glavno ravnateljstvo za zdravstvo, br. 61832-I-1942

74 Isto.

75 Isto.
} 
ca bila cijepljena protiv dizenterije, a redovito su im se davali lijekovi (carbo animalis i tonocardin), zatim fiziološke infuzije, cardijazol, i drugi lijekovi koji su dolazili u obzir." ${ }^{76}$

Prehrana je bila potpuna i prema svim medicinskim propisima, naglasio je Najžar u izvješću. "Djeca su dobivala mlijeko eventualno razrijeđeno čajem, zatim čaj slađen šećerom ili saharinom, prema potrebi i mišljenju liječnika specijalista za dječje bolesti. Davala se juha od sluzi (ječmene ili zobene, najfiniji griz na razne načine pripremljen, kruh od bijelog brašna, itd.). Hrana se nastojala dati na što čistiji i sterilniji način." Ali sve to nije bilo dovoljno, napisao je dr. Najžar, "jer su hladnoća i promjena prehrane bile mnogo jače od svih liječničkih nastojanja".77

Pri smrtnosti u Sokolani također je element bila hladnoća, napisao je Najžar. "Djeca su spavala u velikim skupinama pokraj potpuno otvorenih prozora (kojih zapravo nije ni bilo, već se radilo o otvorima u zidu na nedovršenoj zgradi u koje prozori još nisu bili ugrađeni). Uz to su tu bile i razne zarazne klice - dizenterija, colli, ospice, parotistis epidemica, par slučajeva skarlatine i jedan slučaj paratifusa B. Što se tiče higijenskih prilika te zgrade nisu mogle biti ni uz najveća nastojanja na potrebnoj visini, jer je ovdje bio vrlo veliki broj djece, a sama zgrada je potpuno otvorena, tako da se može reći da je uspjelo da djeca nisu spavala pod vedrim nebom“, naveo je dr. Najžar. ${ }^{78}$

Već je spomenuto da je škola u Novom Sisku bila u mnogo boljem stanju jer je imala uređen vodovod i kanalizaciju. Ondje su prvo bila smještena najzdravija djeca koja su se mogla dati na udomljavanje pa do 22. kolovoza ondje nije bio ni jedan smrtni slučaj. Od tog dana u školu su premještana djeca u najtežem stanju iz Sokolane pa je i ondje zatim zabilježen veći broj smrtnih slučajeva. Slično je bilo i u Solani, koju dr. Najžar opisuje kao veliko skladište koje stoji "na lijepom sunčanom mjestu uz veliko travnato dvorište“. Ondje su također bila poslana zdravija djeca. "Vrlo mali broj slučaja pomora kod ove djece, koje je bilo oko 1200 ide na račun toga zdravog novog mjesta“, napisao je dr. Najžar.79

U istrazi koja je po svršetku Drugoga svjetskog rata pokrenuta protiv dr. Najžara ispitan je i dr. Lazar Margulies ${ }^{80}$, jedan od liječnika koji su se u Sis-

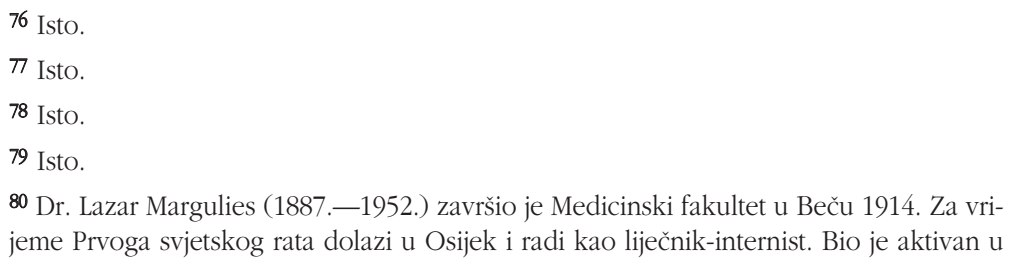


ku brinuli o djeci. On je ustvrdio da se dr. Najžar nije bavio liječenjem djece niti je za to pokazivao naročitu brigu. Dodao je da su se ozbiljno oko djece trudila samo dva liječnika, on, Margulies i dr. Ivan Špicer. Zbog rada s djecom čak su oboljeli od pjegavog tifusa. "No sav je trud bio uzaludan jer je sve bilo loše organizirano i sa strane uprave nije se učinio ozbiljan korak da se infekcije i širenje bolesti zaustave", kazao je dr. Margulies. Tvrdio je i da je hrana bila nezdrava i nedovoljna, a mlijeko većinom pokvareno. Predbacio je dr. Najžaru što je bolesnu djecu iz Sokolane prebacio u školu u Novom Sisku pa je smrtnost i ondje porasla. Navodno ga je dva puta upozorio da će to imati loše posljedice.

Treba uzeti u obzir da se radilo o istrazi kakve su u to vrijeme često završavale najtežim posljedicama za istraživane osobe pa su i svjedoci bili skloni odmaknuti od sebe potencijalnu opasnost kako i sami ne bi bili optuženi. Stoga se i izjave dr. Marguliesa možda mogu promatrati u tom svjetlu. S druge strane, brojni su ostali svjedoci rad dr. Najžara opisivali korektnim i naglašavali njegovu skrb za povjerenu djecu u prihvatilištu kao i onu koja su iz prihvatilišta bila udomljena u Sisku i okolici. Otegotna okolnost za dr. Najžara bila je ta da je istodobno bio i liječnik sabirnog logora u Sisku (za prikupljanje radne snage za Njemačku), što mu je stavljeno na teret u istrazi i sudskom procesu koji je slijedio. Ipak, i dr. Lazar Margulies je u izjavi naglasio da u Sisku nije bilo nasilja ili trovanja djece. ${ }^{81}$

$\mathrm{Na}$ izvješće dr. Najžara reagiralo je Ministarstvo udružbe te 17 . rujna 1942. godine zamolilo Ministarstvo zdravstva da žurno formira povjerenstvo koje očevidom treba utvrditi razloge tako velike smrtnosti u Državnom dječjem prihvatilištu u Sisku, s prijedlogom kako bi se smrtnost mogla smanjiti. ${ }^{82}$ Uskoro su, u listopadu i studenome, skupine djece iz Siska prebacivane u Zagreb i potom udomljavane u obiteljima. ${ }^{83}$

Ukupno je u Sisku do kraja godine umrlo 1156 djece, kako je zabilježio povjerenik, učitelj Ante Dumbović i njegove tri tajnice koje su izrađivale popise djece iz pristiglih transporta (tablica 2). Među umrlima je 751 dijete, odnosno čak 65 posto, upisano u popise bez imena i prezimena iz čega se može zaključiti da se radilo o najosjetljivijoj skupini djece stare do dvije go-

cionističkim organizacijama, loži Bnei Brit i Židovskoj bogoštovnoj općini u Osijeku. Od lipnja 1947. bio je ravnateljem Opće bolnice u Osijeku. Vidi Židovski biografski leksikon (radna verzija), https://zbl.lzmk.hr/?p=1221 (pristupljeno 31. ožujka 2021.).

${ }^{81}$ Državni arhiv u Sisku, Zbirka sudskih predmeta političkih procesa, dr. Antun Najžar, STUP 46/46, 560, izjava dr. Lazara Marguliesa u istrazi protiv dr. Najžara.

82 HDA, 226, Glavno ravnateljstvo za zdravstvo, 61832-Z-1942.

83 HDA 1722, AFŽ, kut. 8/34. 
dine. Najmanja djeca, koja su umrla a da se nije uspio utvrditi njihov identitet, fotografirana su (načinjeno je oko 400 fotografija). ${ }^{84}$

Tablica 2. Smrtnost djece u prihvatilištu u Sisku po mjesecima 1942. godine 85

\begin{tabular}{lrr}
\hline Miesec & $\begin{array}{r}\text { Broj } \\
\text { umrle djece }\end{array}$ & $\begin{array}{r}\text { Prosječni dnevni } \\
\text { broj umrlih }\end{array}$ \\
\hline Kolovoz (25 dana od dolaska) & 537 & 21,48 \\
\hline Rujan & 439 & 14,63 \\
\hline Listopad & 88 & 2,83 \\
\hline Studeni & 84 & 2,80 \\
\hline Prosinac & 8 & 0,26 \\
\hline Ukupno & 1156 & \\
\hline
\end{tabular}

Iz zapisnika i izjava nastalih u ratno i poratno vrijeme može se utvrditi i odnos lokalnih vlasti prema radu liječnika i ostalog osoblja koje je pomagalo pristigloj djeci. U izjavi pred istražiteljima poslije rata dr. Najžar je naveo da su gradski dužnosnici (sisački gradonačelnik Ivan Štirmer i predstavnik ustaškog pokreta logornik Roko Faget) bili zabrinuti da se zarazne bolesti, za koje se znalo da u Sisak dolaze s djecom, ne prošire na stanovnike grada. S druge strane, nisu sprječavali organiziranje liječničke i prehrambene pomoći toj djeci. ${ }^{86}$

Zanimljivo je kako su dr. Najžara nakon nekog vremena predstavnici Ustaške nadzorne službe (tadašnje sigurnosne službe) pozvali na informativni razgovor i sa zabrinutošću ga suočili s glasinama koje se šire po Sisku da se djeci u prihvatilištu "daju neke injekcije od kojih djeca umiru". Dr. Najžar im je objasnio da se radi o infuzijama fiziološke otopine koje se daju jer su mnoga djeca stigla dehidrirana zbog bolesti, osobito zbog dizenterije. Agenti UNS-a prihvatili su to objašnjenje. ${ }^{87}$

Podatci o broju djece zbrinute u Sisku razlikuju se od izvora do izvora — od 4000, preko 5600 do 6500 ili 7000 djece. Prema tome, udio umrle djece iznosio bi 24,40 , odnosno 23,97 , te 20,55 ili 16,56 posto. 88

${ }^{84}$ HDA, ZKRZ-GUZ, 4676/45, izjava Ante Dumbovića od 25. svibnja 1946.; HDA 1722, AFŽ, kut. 8/27, izjava A. Dumbovića od 8. veljače 1946.

85 HDA 226, Glavno ravnateljstvo za zdravstvo br. 61832-I-1942, tablica "Pomor djece“, prilog izvješću dr. Najžara.

86 HDA, 1722, AFŽ, kut. 8/48.

87 Isto.

88 Nataša MATAUŠı́́, nav. dj., 353. Autorica donosi preglednu tablicu s izvorima za pojedine brojeve zbrinjavane djece i postotke umrlih. Tako navodi da je prema podatci- 


\section{Zavod za odgoi gluhonijeme diece u Zagrebu}

Jedno od glavnih mjesta za prihvat djece u Zagrebu i privremeni boravak prije no što bi bila poslana na liječenje, u druge domove ili obitelji, bio je Zavod za odgoj gluhonijeme djece u Ilici 83.89 Onamo su smještana djeca stara od 3 do 16 godina. Odatle je u razne bolnice u Zagrebu premješteno 237 djece. Kroz Zavod je prošlo 5612 djece koja su potom udomljavana uglavnom putem Caritasa ili bi bila smještena u neka druga manja prihvatilišta. Prilikom prijama u Zavodu su ih pregledavali liječnici koji su utvrdili 38 različitih dijagnoza u 30.246 pregleda, odnosno u svakog djeteta prosječno više od pet bolesti.90 U samom Zavodu umrlo je 157 djece. Takva, relativno mala smrtnost u odnosu na veliki broj djece što su prošla kroz Zavod u jednom se poratnom izvještaju objašnjavala nešto starijom dobi djece koja su boravila u Zavodu, pa su se lakše privikavala na prehranu i bila otpornija.91

Zavod za odgoj gluhonijeme djece javio je Ministarstvu udružbe 8. srpnja 1942. godine da je skrb za pristiglu pravoslavnu djecu povjerio dobrovoljnim sestrama Crvenoga križa od kojih su dvije, Sara Abinun i Katarina Jambrišak, stalno u Zavodu, a Vera Černe i Anka David dolaze svakodnevno kao dodatna ispomoć. Osim njih zaposleno je "još nekoliko zdravih, bistrih i urednih žena za pripomaganje oko bolesnika». Uz ostalo, izvješćuje se da je od 102 zaprimljena slučaja proljeva odnosno dizenterije u međuvremenu ozdravilo 96 osoba, a jedna (Pelka Zaklanac) je umrla. Svrab je liječen u 160 slučajeva i uglavnom izliječen. "Kako se iz prednjeg izvještaja vidi, poduzeto je sve da se ove opasne i nemile zaraze koje su i donesene u ovaj zavod, sa svim raspoloživim sredstvima suzbiju. Na ovom mjestu potrebno je istaći požrtvovni i neumorni rad cjelokupnog pomoćnog i službujućeg osoblja, koje je bez obzira na laku mogućnost opasne zaraze i ogromnog posla svoju dužnost obavljalo savjesno i točno prema uputama liječnika na najveće zadovoljstvo«, stoji u izvješću.92

ma iz fonda HDA 1722, AFŽ log 23/3 i 3a u Sisku bilo 5602 djece, a umrlo je 1152, što daje 20,55 posto. Prema podatcima iz pisma učitelja Ante Dumbovića, voditelja administracije sisačkog prihvatilišta, u Sisku je prihvaćeno 6954 djece, od čega je umrlo 1152 djece (16,56 posto). Dragoje Lukić u knjizi Bili samo deca iz 2000. godine piše o 6693 prihvaćene djece, a umrlo je 1601 (23,97 posto). Publikacija Žene Hrvatske u NOB-u, Zagreb, 1955., na str. 177 donosi podatak o 7000 djece, od kojih je umrlo 1701, što daje postotak od 24,40 posto.

89 HDA 1722, AFŽ, kut 8/31.

90 Isto. Brojidbeni pregled slučajeva za 1942. godinu izradili su upravitelj Zavoda dr. Ljudevit Šafarić i liječnik dr. Franjo Perše, a nosi nadnevak 1. siječnja 1943.

91 HDA 1722, AFŽ, kut 8/31. 
Potkraj 1942. godine Ministarstvo zdravstva odlučilo je u Zavodu osnovati podružnicu Bolnice za zarazne bolesti. "U ovo doba porasta zaraznih bolesti na području grada Zagreba i okolici, na prvom mjestu škrleti (šarlaha, nap. a.) i difterije, gradska Zarazna bolnica u Zagrebu je jako preopterećena budući da se u njoj trenutno nalazi 254 bolesnika na 180 raspoloživih kreveta. Zbog te preopterećenosti dolazi do neugodnih posljedica osobito prigodom primanja u bolnicu većih skupina bolesne izbjegličke djece koja obično dolaze u inkubaciji drugih zaraznih bolesti te uslijed nemogućnosti potpune izolacije kao i pomanjkanja izvježbanog osoblja. Stoga pojedine bolesti prelaze s izbjegličke djece na zagrebačku u drugim paviljonima", stoji u obrazloženju odluke koju je potpisao dr. Ivo Stipčić, glavni ravnatelj za zdravstvo.

Objašnjava se da je II. paviljon bolnice, koji je služio kao odterećenje za slučaj potrebe smještaja većeg broja bolesnika, zauzet izbjegličkom djecom (ukupno 55) pa ne postoji ni jedno raspoloživo mjesto za slučaj potrebe u žurnom izdvajanju zaraznih bolesnika s područja grada i okolice. Stoga je odlučeno da se gornji kat Zavoda za gluhonijemu djecu pretvori u Privremenu epidemijsku bolnicu za izbjegličku djecu. U odluci stoji da će Glavno ravnateljstvo za zdravstvo preuzeti sve troškove liječenja, dodijeliti liječnike i pomoćno osoblje te provesti sve zaštitne mjere da se onemogući prijenos zaraze na okolinu, dok bi Glavno ravnateljstvo za udružbu preuzelo troškove prehrane. 93 I iz ovog dokumenta jasno se vidi da je zbog loših epidemioloških prilika i u civilnom, odnosno gradskom stanovništvu bio veliki broj oboljelih od zaraznih bolesti te da su način i mjesto liječenja istovjetni za izbjeglice s Kozare i za druge bolesnike.

\section{Diečji dom na Josipovcu u Zagrebu}

Dojenčad (djeca mlađa od 12 mjeseci) koja su u izbjegličkim skupinama stizala u Zagreb smještana su u Dječji dom na Josipovcu (danas je to dječji dom u Nazorovoj ulici). Prvi transport sa šezdesetero djece stare od nekoliko dana do tri godine i svega nekoliko starijih stigao je u dom 3. srpnja 1942. godine oko šest sati ujutro, bez ikakvih prethodnih priprema i najava. ${ }^{94}$ Djecu su u Zagreb iz Stare Gradiške dopratili ustaše. Djeca su također bolovala od različitih zaraznih bolesti. Prostor u domu bio je prenapučen što je pogodo-

\footnotetext{
92 HDA 226, Glavno ravnateljstvo za udružbu 51769-I-2, izvještaj br. 641 od 8. srpnja 1942. (nadopuna izvještaja br. 627), potpisao ravnatelj zavoda Ljudevit Šafarić.

93 HDA 226, Glavno ravnateljstvo za zdravstvo, br. 78330-Z-II-1942, od 15. prosinca 1942.

94 Nataša MATAUŠIĆ, n. dj., 177.
} 
valo i dodatnom širenju bolesti. Najteže bolesna djeca upućivala su se u Zaraznu bolnicu.

Iz prvog transporta 3. srpnja na Josipovcu je umrlo 15, a u Zaraznoj bolnici 24 djece. Zatim je 31. srpnja primljeno 40 djece, od čega je na Josipovcu umrlo 25, a u Zaraznoj bolnici 12. Dana 3. kolovoza primljeno je 112, umrlo 90 (u Zaraznoj bolnici 4), dok je od 85 djece primljene 14. kolovoza umrlo 61.95 Za posljednji transport od 14. kolovoza navedeno je da je stigao iz Bosanske Gradiške. Vjerojatno se radilo o djeci pronađenoj »ispod Kozare, gladnoj i oboljeloj od dizenterije, koja su umiruća odvedena Crvenom križu u Zagreb،, kako stoji u izvještaju Velike župe Livac-Zapolje od 19. kolovoza 1942.96

Transporti male djece i dojenčadi iz Siska stizali su na Josipovac i tijekom rujna i listopada 1942. godine. U to vrijeme gotovo sva mjesta u Zagrebu za smještaj bolesne djece već su bila popunjena. Ukupno je od 3. srpnja do 2. studenoga 1942. u dom na Josipovcu dovezeno 746 djece, od kojih je u domu umrlo 553, a 75 u Zaraznoj bolnici. Zabilježeni su i smrtni slučajevi djece koja su predana na skrb pojedinim obiteljima. Kako se radilo o vrlo maloj djeci, više od polovice prispjelih (388) uvedeno je u kartoteku doma u Josipovcu kao N.N., bez imena i prezimena i bez ikakvih drugih podataka osim naznake približne starosti.97

\section{Rasprava uz osvrt na opće zdravstvene prilike}

Na temelju dostupnih podataka o prihvatu i zbrinjavanju djece s Kozare i Potkozarja, ustroju prihvatilišta te organizaciji prehrane i zdravstvene skrbi, nedvojbeno se može tvrditi da su ta djeca imala odgovarajuću skrb sukladnu ratnim uvjetima općeg siromaštva i higijenske zapuštenosti, pri proširenoj ušljivosti i pravim epidemijama raznih zaraznih bolesti, uz nedostatak lijekova i medicinskog osoblja. Dakle, djeca u prihvatilištima nisu bila medicinski zanemarivana i diskriminirana u pogledu zdravstvene skrbi.

\footnotetext{
95 Narcisa LENGEL-KRIZMAN, n. dj., 62. Autorica je podatke pronašla u arhivi Zarazne bolnice.

96 Antun MILETIĆ, n. dj., knjiga I, dok br. 169, 428-429; u dokumentu piše "oboljele od dizenterije i to od grupe Fleksner" što se odnosilo na uzročnika dizenterije, bakteriju Shigella flexneri.

97 Narcisa LENGEL-KRIZMAN, n. dj., 61; Nataša MATAUŠIĆ, n. dj., 353. Izrazito visok postotak smrtnosti u domu na Josipovcu u 1942. godini spominje se i u izvješću dr. Olge Bošnjaković, upraviteljice Državnih dječjih kolonija i sabirališta na Josipovcu. Prema tom izvješću, dovezena djeca bila su stara od 2 dana do 3 godine, a u najvećem se broju slučajeva radilo o djeci mlađoj od godinu dana. Djeca su došla već bolesna, od tifusa i dizenterije, što je i rezultiralo ogromnim postotkom smrtnosti. Izvješce dr. Bošnjaković u: HDA 226, kut. 24, bez urudžbenog broja; N. MATAUŠIĆ, n. dj., 353.
} 
Postoje brojni dokumenti koji pokazuju da je odmah nakon sloma partizanske pobune na Kozari za izbjeglo civilno stanovništvo formirano više prihvatnih centara (Stara Gradiška, Mlaka, Jablanac, Uštica, Jasenovac, Novska). ${ }^{98} \mathrm{U}$ te su centre po nalogu Ministarstva zdravstva i Ministarstva udružbe odmah upućivani liječnici, medicinske sestre i drugo osoblje. Već tada, sredinom srpnja, organizirana je ondje nužna zdravstvena skrb (depedikulacija, improvizirane su bolnice, obavljani liječnički pregledi te provođeno cijepljenje protiv trbušnog tifusa i dizenterije). Potom se formiraju dječja prihvatilišta, uglavnom nakon razdvajanja djece od majki, koje su slane na rad u Njemačku.

Razdvajanje djece od majki bio je svakako jedan od glavnih čimbenika koji je uvelike pridonio velikoj smrtnosti, osobito najmanje djece. Međutim, nakon bitke nisu svi zarobljenici i radno sposobne izbjeglice s Kozare i Potkozarja bili upućivani u njemačke tvornice i na poljoprivredna dobra. Hrvatske su vlasti uputile nekoliko desetaka tisuća tih izbjeglica u zapadne dijelove Slavonije, sjeverno od Save (upućivani su vlakom i drugim prijevoznim sredstvima od Jasenovca do Lipika, Garešnice, Daruvara, Bjelovara i dalje). 99 Tamo su odlazila djeca zajedno s majkama i drugim članovima obitelji (najčešće ženskim te starijim muškarcima). U tim su selima raspoređeni na stanovanje i pomaganje domaćinima u poljskim radovima. U srpnju 1942. godine Velika župa Bilogora izvijestila je Ministarstvo unutarnjih poslova da je na njezino područje od 14. do 16. srpnja stiglo 16.500 "zarobljenika s Kozare ${ }_{100}$ Ujedno je izviješteno "da su zarobljenici s Kozare došli puni ušiju pa treba provesti njihovu dezinfekciju i raskuživanje ${ }^{101}$ Iako je i među tom populacijom djece bilo zaraza i smrtnih slučajeva, njih je ipak bilo znatno manje nego među najmanjom djecom smještenom u prihvatilištima.

Već je spomenuto da su u početku u Njemačku u transportima odlazile cijele obitelji. Ali nakon što su u prihvatnim centrima u Mariboru ili Linzu njemački liječnici ustanovili da im stižu bolesni ljudi, a bolesti su se najbrže

98 U arhivima je moguće pronaći niz izvješća vladinog opunomoćenika Oskara Turine iz Banje Luke, već navedena izvješća Glavnog ravnateljstva za zdravstvo iz 1942. godine, izvješća mjesnih tijela vlasti te oružništva i vojske, a koja se odnose na zbrinjavanje izbjeglog pučanstva u prihvatnim centrima.

99 Antun MILETIĆ, n. dj., knjiga III., dok. br. 85, str. 200, Izvješce Mihajla Komunickog o obilasku prihvatnih centara, gdje se navodi kako su izbjeglice iz Uštice u Lipik prevezeni u dobro zatvorenim vagonima te su u Lipiku poduzete sve mjere kako se ne bi sporadični slučajevi pjegavog tifusa proširili na gradsko stanovništvo.

100 NDH, Glavni stožer Ustaške vojnice, Glavnostožerni odjel, Taj. broj: 678/1942., faksimil dokumenta objavljen u: D. R. Vasović, Waldheim, jedna karijera, 386-387.

101 HDA 226, Glavno ravnateljstvo za zdravstvo, br. 48.254-Z-1942. 
širile među djecom, vraćali su te transporte natrag i tražili da dolaze samo zdravi odrasli radnici, a "djecu na brigu treba preuzme hrvatska država".102

Hrvatske vlasti morale su se tada suočiti s velikim brojem ostavljene djece, od kojih su mnoga već bila teško bolesna. Iako su već 1941. i u prvom dijelu 1942. godine stizale veće skupine izbjegličke djece, bježeći s drugim članovima obitelji od četničkih pokolja (iz istočne Bosne, sjeverne Dalmacije, Kulen Vakufa, Bosanskog Grahova i okolice itd.), ${ }^{103}$ novi val izbjeglica, a osobito djece s Kozare i Potkozarja, nadmašio je sva očekivanja i izazvao veliku humanitarnu nevolju. Problemi sa smještajem izbjeglica pojavljivali su se gotovo u svim gradskim središtima. Tako je u Osijek u srpnju 1942. godine primljeno oko 400 izbjeglica (Hrvata i Muslimana) iz Bosne i Hercegovine. U izvješću gradskog kotarskog liječnika upućenom Gradskom fizikatu stoji kako su "izbjeglice smještene u jednoj od škola, leže na slami, a dio ih spava pod vedrim nebom u dvorištu. U kratkom roku umrlo je 19 djece stare do sedam godina i jedna žena. Izbjeglice imaju slabu prehranu (15 dkg kruha, 12 dkg graha i $12 \mathrm{dkg}$ kukuruznog brašna po osobi dnevno), a mnogi boluju od crijevnih bolesti što zahtijeva posebnu prehranu, koju im je teško osigurati،. ${ }^{104}$

Panorama dječjih zaraznih bolesti danas se potpuno promijenila u odnosu na klasične zarazne bolesti s masovnim (epidemijskim) pojavljivanjem i visokom stopom smrtnosti u Drugom svjetskom ratu. Tadašnje ratne zarazne bolesti, pratiteljice bijede i siromaštva, imaju najveću učestalost i smrtnost upravo u male djece. Praćene su visokom temperaturom i vrlo teškom kliničkom slikom s posljedičnim brzim razvojem dehidracije (gubitak tekućine), osobito u pothranjene djece u vrlo lošim higijenskim prilikama. Osim u dječjim prihvatilištima, te su se bolesti redovito pojavljivale u obliku manjih ili većih epidemija i u sve druge djece. ${ }^{105}$ Najvažnije su bile:

- Dizenterija (griža), teški toksični oblik bolesti s krvavim proljevom i brzom dehidracijom djece. Uzročnik je Shigella dysenteriae, koja se danas ne pojavljuje. To je bila svakako najteža, a vrlo učestala ratna dječja bolest $s$ temperaturom i velikim brojem vodenastih stolica što dovodi do brze dehidracije male djece i nerijetko smrtnog ishoda.

- Pjegavac (pjegavi tifus), teška akutna febrilna bolest s osipom koju prenose uši, a zahvaća brojne organe. Iskorijenjena je nakon Drugoga svjetskog rata.

\footnotetext{
102 Antun MILETIĆ, n. dj., knjiga I., dok. br. 137, str. 357; vidi bilješku 27 u ovom radu.

103 Dossier Boričevac, n. dj., 435.

104 Državni arhiv Osijek, Gradsko poglavarstvo Osijek, fond 6, kut. 5350.

105 Klinička infektologija, ur. Josip Begovac i sur., Zagreb, Medicinska naklada, 2019.
} 
- Trbušni tifus, teška i iscrpljujuća zarazna bolest koja zahvaća gotovo sve organe. Danas se ne pojavljuje nigdje u Europi.

- Morbili (ospice), lako prenosiva dječja zarazna bolest s epidemijskim pojavljivanjem svake godine, često praćena upalom pluća. Danas gotovo iskorijenjena.

- Tuberkuloza, kronična, iscrpljujuća zarazna bolest, pratitelj loših socijalnih (ratnih) prilika.

- Difterija, epidemijska bolest s teškim upalnim promjenama u gornjem dijelu dišnog sustava.

U Drugom svjetskom ratu antibiotici još nisu bili u redovitoj primjeni, a nisu postojala ni cjepiva za uspješno sprječavanje bolesti. Doduše, u nekim situacijama primjenjivala su se cjepiva protiv trbušnog tifusa i dizenterije, ali s vrlo dvojbenim učinkom. U izvješću liječnika iz prihvatnih centara za izbjeglice u Jablancu i Mlaki uz ostale poduzete mjere navedeno je i cijepljenje. Isto tako dr. Najžar u svojem izvješću navodi da je cijepio djecu protiv dizenterije u prihvatilištu u Sisku. ${ }^{106}$ Dakle, nije bilo učinkovitih lijekova pa se liječenje zaraznih bolesti sastojalo u simptomatskim mjerama pri čemu je najvažnija rehidracija (nadoknada tekućine) infuzijskim otopinama ("vodene injekcije ") te odgovarajuća dijetna prehrana, odnosno lako probavljiva hrana bez masnoća i šećera.

Djeca su dolazila u prihvatilišta nakon više tjedana provedenih u zbjegu, odvojena od roditelja, iznimno iscrpljena, izgladnjela i atrofična, ušljiva, higijenski potpuno zapuštena, a većina njih i s jednom ili više zaraznih bolesti. Veliki broj djece već je bio na putu, odnosno u zagrljaju smrti. Uzevši u obzir opće i zdravstveno stanje djece pridošle u prihvatilišta s vrlo nepovoljnim uvjetima prenatrpanog smještaja, nerijetko i bez tekuće vode te uz haranje zaraznih bolesti, ne začuđuje visoka stopa pobola i smrtnosti.

O stanju djece pri dolasku u prihvatilišta, odnosno njihovoj izmučenosti, pothranjenosti i težini brojnih pratećih bolesti upečatljivo govore podaci o najvećoj smrtnosti u prvom mjesecu boravka. U Jastrebarskom je za 20 dana u srpnju (12. - 31. srpnja 1942. godine) umrlo 153 djece, odnosno prosječno 7,65 na dan. U kolovozu i rujnu prosječno je dnevno umiralo 3,54 djece, odnosno 54 posto manje nego u srpnju. Ustrojavanje bolnice, bolja organizacija zdravstvene skrbi te poboljšanje prehrane i higijenskih uvjeta u prihvatilištu rezultirali su bitno manjim pobolom i smrtnosti djece.

Slični su rezultati postignuti i u Dječjem prihvatilištu u Sisku. U prvih 25 dana rada u kolovozu (7. - 31. kolovoza 1942.) umrlo je 537 djece, odnosno prosječno dnevno 21,48. U rujnu je umrlo 439, odnosno 14,63 na dan, što 
je 33 posto manje nego u prethodnom mjesecu. Smrtnost u listopadu i studenom naglo se smanjuje na 2,8 djece dnevno. U popisu svih umrlih u sisačkom prihvatilištu 751 dijete, odnosno 65 posto, upisano je bez imena i prezimena. Budući da ne postoje vjerodostojni podatci o dobnoj strukturi djece u prihvatilištu, najlogičnija je pretpostavka da nije bio poznat identitet najmanje djece, odnosno dojenčadi koja su imala najveću smrtnost.

U Zavodu za odgoj gluhonijeme djece u Zagrebu organiziran je prihvat s kraćim boravkom za ukupno 5612 djece koja su upućivana na liječenje u bolnice (poglavito Bolnicu za zarazne bolesti), u druge domove ili obitelji. Budući da su u Zavod prihvaćana samo djeca starija od tri godine zabilježena je relativno mala smrtnost. U samom Zavodu umrlo je 157 djece, a za 237 djece premještene $u$ bolnice nisu poznati podaci o smrtnosti.

Znatno gore stanje smrtnosti djece zabilježeno je u Dječjem domu na Josipovcu gdje su smještana samo dojenčad (djeca do 12 mjeseci života) i mala djeca do tri godine. Tamo je od 3. srpnja do 2. studenoga 1942. godine dovedeno ukupno 746 djece, od kojih je u domu umrlo 553 te 75 u Bolnici za zarazne bolesti.

Pri raščlambi uzroka pobola i smrtnosti u prihvatilištima, ali i među svom djecom, treba znati da je najvažniji prediktor dob djeteta. Iz prihvatilišta su najčešće u obitelji udomljavana veća djeca bez vidljivih znakova bolesti jer su udomitelji radije prihvaćali stariju i vitalniju djecu.

Tu tvrdnju potkrjepljuju podatci o pobolu i smrtnosti 100 kozaračke djece kolonizirane u obiteljima u bjelovarskom kraju, a liječene u Državnoj bolnici u Bjelovaru od kolovoza 1942. do lipnja 1943. godine. ${ }^{107}$ Na skrb i njegu, bez dijagnoze bolesti, zaprimljeno je 21 dijete (šestero mlađih od 3 godine), a na bolničko liječenje 79 djece od kojih je 10 umrlo. Za razumijevanje situacije s pobolom i smrtnosti djece prema dobi važno je napomenuti da je samo jedno dijete zaprimljeno zbog bolesti bilo mlađe od godinu dana (8 mjeseci). Najčešći razlog hospitalizacije bio je svrab sa sekundarnom kožnom infekcijom, a zbog proljeva je zaprimljeno samo desetero djece. Ukupno je umrlo 10 djece (smrtnost je dakle 10\%), a glavni razlog nije dizenterija (kao u prihvatilištima), jer je riječ o starijoj djeci, nego tuberkuloza u dva slučaja i trbušni tifus (u dvoje djece). Jedino hospitalizirano dojenče (8 mjeseci) umrlo je od dizenterije. ${ }^{108}$

\footnotetext{
107 Dubravko HABEK, "Djeca iz Potkozarja zaprimljena na skrb i liječenje u Državnu bolnicu u Bjelovaru 1942.-1943. godine“, Radovi Zavoda za znanstvenoistraživački i umjetnički rad u Bjelovaru, Bjelovar, 2020.

108 Ostala djeca primljena u bjelovarsku bolnicu umrla su od hripavca udruženog s dizenterijom, od gangrene, difterije i upale pluća; vidi: isto.
} 
No, pri objektivnom sagledavanju sveukupnog tadašnjeg stanja nužno je napomenuti da su pobol i smrtnost djece, u to ratno doba s posvemašnjom neimaštinom i ograničenim mogućnostima zdravstvene skrbi, bili vrlo visoki i u općoj populaciji pa i među gradskom djecom. Iz današnje perspektive takvu smrtnost djece ne možemo ni zamisliti.

Stanje se najbolje može sagledati na primjeru grada Osijeka iz podataka koje donosi Hrvatski list 8. kolovoza 1943. godine s naslovom "Porod i pomor djece u Osieku». U prvoj polovici 1943. godine na osječkom području rođena su 464 djeteta, a umrlo je 82, odnosno 17,75 posto. U prethodnoj, 1942. godini smrtnost djece bila je još veća, 24 do 28 posto mjesečno, pa se smanjenje smrtnosti u 1943. godini smatra rezultatom velikog zauzimanja gradskog poglavarstva. Međutim, u mjesecu srpnju te godine smrtnost je iznosila čak 30 posto ("uslijed velike ljetne žegeu). To se objašnjava kao redovita pojava u ljetnim mjesecima, s teškim oblikom proljeva i dehidracijom male djece. ${ }^{109}$

Isto tako, u izvješću Gradskog poglavarstva Osijek Velikoj župi Baranja od 7. siječnja 1943. godine navodi se da je do navršene druge godine života 1940. godine umrlo 130 djece (25 posto), 1941. godine 110 (17 posto), a 1942. godine 266 djece (23 posto). Najčešći uzrok smrti bio je enterokolitis.

Ti osječki podatci, osobito za 1942. godinu, mogu se, ali s vrlo velikim oprezom, donekle uspoređivati sa smrtnošću u prihvatilištima za djecu s Kozare. Treba znati da je smrtnost u prvoj godini života (dojenčad) znatno veća u prva tri mjeseca nego kasnije. Od ukupno 266 umrle djece u Osijeku 1942. njih 232 umrlo je u prvoj godini života, a samo 23 djece u drugoj godini, uz 11 mrtvorođenih. Od 232 djeteta umrla u prvoj godini, njih 168, odnosno 72,4 posto umrlo je u prva tri mjeseca života. ${ }^{110}$ Zato se smrtnost u prihvatilištima, gdje su bila smještena sva djeca do 14 godina, a čini se da ih je dosta bilo mlađih od godinu dana (nema točnih podataka o broju djece po godinama života), ne može izravno uspoređivati sa smrtnošću djece u Osijeku. ${ }^{111}$

109 Hrvatski list, Osijek, 8. kolovoza 1943., 21.

110 Državni arhiv Osijek, Gradsko poglavarstvo Osijek 1941-1945, izvješće Pododsjeka Skrb za majke i djecu, podneseno Velikoj župi Baranja od 7. siječnja 1943., potpisao donačelnik mr. Franjo Helfrich .

111 Iako se dojenačka smrtnost na godišnjoj razini ne može izravno uspoređivati sa stanjem u dječjim prihvatilištima u Drugom svjetskom ratu, može se ipak spomenuti da se izrazito visoke stope dojenačke smrtnosti u Hrvatskoj bilježe sve do kraja Drugoga svjetskog rata. Bilo je razdoblja smanjivanja, ali i povećavanja, primjerice početkom Prvoga svjetskog rata (sa stope smrtnosti od 181,3 na 1000 živorođene djece u 1914. godini, na 265,5 u 1915. godini). Godine 1931. stopa smrtnosti iznosila je 201,4, potom je godine 1934. bila 171,5, 1939. zabilježena je stopa od 146, 7, a 1949. godine iznosila je 
Iz današnje perspektive, kada je u Hrvatskoj stopa smrtnosti dojenčadi 4,2 na 1000 živorođene djece, a djece od 1-19 godina samo 0,12 na 1000, podatak o smrtnosti djece u Drugom svjetskom ratu u Osijeku jednako je zastrašujući kao i smrtnost u dječjim prihvatilištima. ${ }^{112}$

O općem i zdravstvenom stanju djece pri prihvatu u prihvatilišta te o žurno poduzimanim mjerama za njihovo zbrinjavanje i liječenje govore brojna izvješća odgovornih osoba tadašnjim vlastima kao i sačuvani dokumenti o iskazima osumnjičenih osoba ili svjedoka u procesima vođenim nakon rata. Navodimo nekoliko primjera.

U izvješću o prihvatu prvog transporta s 850 djece u Jastrebarsko, 11. srpnja 1942. godine Kamilo Bresler navodi: "Orijentacijskim pregledom utvrđeno da je barem 400 djece teško bolesno, stotina najmanje osuđena na smrt, od toga 10 danas umrlo“. Dalje kaže da su odmah pri dolasku najteže bolesna djeca smještena u posebnu nastambu (dvorac). Istodobno potražuje liječnike, sestre pomoćnice, raskužitelja (radi rješavanja ušljivosti), bijele ogrtače za osoblje te najnužniju opremu za stacionar, medicinski materijal i lijekove. Zatražene potrepštine otpremljene su istog dana u Jastrebarsko. ${ }^{113}$

Dr. Branko Dragišić, liječnik u prihvatilištu u Jastrebarskom, uz pojedinačne zarazne bolesti navodi i kombinacije, odnosno više zaraznih bolesti u pojedine djece, npr. tifus - dizenterija — ospice - difterija. On je odmah organizirao i vodio improviziranu bolnicu (u dvorcu) sa 110 kreveta u kojoj su djeca odvajana u posebne odjele prema vrsti bolesti, nastojeći tom temeljnom epidemiološkom mjerom izolacije spriječiti prijenos pojedinih zaraznih bolesti. Tako se navode odjeli za tifus, dizenteriju, difteriju i ospice. Kasnije, s pristizanjem novih transporta prošireni su kapaciteti bolnice i izvan dvorca (u barakama). Djecu s najtežim bolestima slali su u zagrebačke bolnice (Bolnica za zarazne bolesti, Dječja klinika). ${ }^{114}$

Dr. Dragišić je organizirao i prihvat 147 djece iz Gornje Rijeke kod Križevaca koja su u velikom broju bolovala od pjegavca. Postojala je velika opasnost da se pjegavac proširi u cijelom prihvatilištu, zato je za novopridošlu djecu organizirana karantena, odnosno stroga izolacija od ostale djece u ispražnjenom franjevačkom samostanu. 115

\footnotetext{
112,0; nav. prema: Aida MUJKIĆ i sur., "125 godina praćenja dojenačke smrtnosti u Hrvatskoj (1874-1999), Liječnički vjesnik, godište 126, 2004., 1-6.

112 Dojenačka smrtnost u Hrvatskoj u 2018. godini, Hrvatski zavod za javno zdravstvo, listopad 2019., www.hzjz.hr/wp-content/uploads/2019/10/Dojenake_2018.pdf (pristupljeno 24. studenoga 2020.).

113 Ćiril PETEŠÍĆ, n. dj., 77.

114 Isto, 25.

115 Isto, 96-101; ZKRZ GUZ, 4676/45.
} 
U svom iskazu dr. Dragišić navodi da je u Jastrebarskom ukupno umrlo 444 djece od 3400 smještene (13,1 posto), a da je 118 djece iz prihvatilišta upućeno u Dječju kliniku u Zagreb na liječenje ( 42 je izliječeno, 35 je otpušteno u poboljšanom stanju, 32 je umrlo, 4 neizliječeno i 5 premješteno u druge bolnice). Nepoznati broj djece iz Jastrebarskog liječen je i u Bolnici za zarazne bolesti te na Dječjem odjelu bolnice na Rebru. ${ }^{116}$

Dr. Anton Najžar, voditelj Školske poliklinike u Sisku, imenovan je početkom kolovoza 1942. godine voditeljem, odnosno nadstojnikom novoosnovanog Dječjeg prihvatilišta u Sisku. Nakon rata, 1946. godine u režiranom sudskom procesu optužen je i osuđen na smrt strijeljanjem — uz ostalo i zato »što je primio dužnost glavnog i odgovornog liječnika u prihvatilištu te što se nije brinuo o djecin.117

Evo nekih njegovih iskaza sa suđenja:

"Prije svega moram naglasiti svoje mišljenje da sam kao liječnik bio obvezan i moralno i pozitivnim zakonom primiti se dužnosti organiziranja i izdavanja liječničke pomoći svakom potrebnom a naročito bolesnoj djeci u onom zdvojnom stanju u kojem su došla u Sisak. Liječnik ne smije nikome uskratiti liječničke pomoći, što ju od njega zatraži a pogotovu ne smije to uskratiti kad mu to kao činovniku naloži njegova pretpostavljena vlast.“118

Opisao je i način prijama pridošle djece: "Zabrinuti sisački liječnici već po dolasku zaražene djece održali su sastanak o tome kako zaštititi Siščane od zaraza koju su djeca donijela u grad. Na sastanku je zaključeno da se djeca izoliraju od gradske djece. To je postignuto tako što sam dao napraviti žičanu ogradu ispred Sokolane i škole gdje su djeca imala prostor za sunčanje i za igranje, a s obzirom da su ti prostori bili ograđeni time su djeca logora bila odijeljena od gradske djece. Osim toga je zaključeno na sastanku da se što više povede računa oko razušivanja djece i kolonizaciji.“119

Dao je i opću ocjenu zdravstvene skrbi koju su pružili malim bolesnicima: "Ni Zagreb sa svim svojim bolnicama i svojim liječnicima kad bi sve bolnice bile preudešene za tu djecu, ne bi ih mogao spasiti od smrti pa kako bi onda Sisak bez potrebnih ili bolje reći bez ikakvih prostorija, mogao tu djecu smjestiti bolje nego što ih je smjestio? Učinilo se sve što je bilo moguće, a za nemoguće ne može nitko biti odgovoran. “20

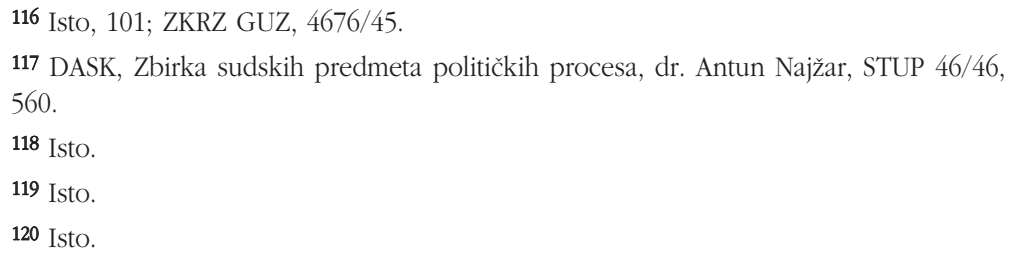


Iz brojnih dokumenata vidljiva je relativno dobra koordinacija ondašnjih državnih (Ministarstvo zdravstva, Ministarstvo udružbe) i lokalnih vlasti, Crvenoga križa i institucija Katoličke crkve pri zbrinjavanju velikog broja djece u ovoj velikoj ratnoj humanitarnoj akciji. 121 Vlasti su dopustile djelovanje i privatnih volonterskih skupina koje su sudjelovale u preuzimanju djece ( $\mathrm{pa}$ i izravno od majki koje su odlazile u Njemačku), zatim prijevozu djece, prikupljanju hrane i odjeće, vođenju kartoteke zbrinute djece i slično. Pri tome valja istaknuti skupinu volontera koju je vodila Zagrepčanka Diana Budisavljević. ${ }^{122}$

$$
\text { Zaključak }
$$

U zadanim ratnim okolnostima i uz ograničene mogućnosti tadašnje medicine djeca s Kozare, Potkozarja i okolice u prihvatilištima zasigurno nisu bila diskriminirana u pogledu zdravstvene skrbi. Uz svakodnevnu liječničku i ostalu stručnu medicinsku skrb te brigu o higijeni i prehrani, izrazito bolesna i iznemogla djeca smještana su u improvizirane bolnice i razvrstavana na pripadajuće odjele prema vrsti bolesti. Iz svih prihvatilišta djeca su upućivana i u gradske bolnice na specijalističke preglede i liječenje. Liječnici i prateće osoblje (medicinske sestre, časne sestre i drugi) brinuli su se nesebično o povjerenoj im djeci. Umorni od velikog posla i sami su se razbolijevali od zaražene djece. U Jastrebarskom je umrla časna sestra Terezija Lukrecija Mlakar zarazivši se od djece o kojoj se brinula. ${ }^{123}$ Smrtnih slučajeva bilo je i u obiteljima koje su na skrb preuzele djecu iz prihvatilišta.

Najveća prihvatilišta (Jastrebarsko, Sisak, Zavod za odgoj gluhonijeme djece u Zagrebu) prihvaćala su i zbrinjavala djecu tijekom nekoliko mjeseci u drugoj polovici 1942. godine. Većinu djece iz prihvatilišta nastojalo se i us-

121 U dopisu ministra udružbe Lovre Sušića Ministarstvu zdravstva od 1. kolovoza 1942. navodi se: "Zahvaljujući uspješnoj suradnji s Ministarstvom zdravstva uspjelo je u najkraće vrijeme urediti veliko dječje prihvatilište za djecu iz sabirnih logora u Jastrebarskom. Pomenuto prihvatilište sada je napunjeno te se ukazala potreba osnutka novog prihvatilišta u Sisku. U tom pravcu poduzete su već sve potrebne mjere te prvi transport djece dolazi u Sisak 3. VIII. o. g. Slobodan sam stoga zamoliti, da Ministarstvo zdravstva i za ovo prihvatilište pruži svoju suradnju dodjeljivanjem na rad liečnika pediatra, te dovoljnog broja sestara pomoćnica kao i ostalog zdravstvenog osoblja i tvoriva. Zahvaljujući Ministarstvu zdravstva na odličnoj suradnji u Jastrebarskom uvjeren sam da će uspjeti povoljno riešiti i ovaj novi zadatak.", HDA 226, Glavno ravnateljstvo za zdravstvo, broj 49534-Z-II-1942

122 Dnevnik Diane Budisavljević; Nataša MATAUŠIĆ, n. dj.

123 I liječnici dr. Župan, dr. Auf i drugi iz skupine koja je bila u srpnju 1942. u Jablancu u izvješću opisuju teške uvjete u kojima su zatekli izbjeglice s Kozare: uz nedostatak hrane, ni liječnici nisu mogli spavati od buha, stjenica i komaraca, i u Zagreb su se vratili iscrpljeni od nesanice i stalnog proljeva, HDA 226, Glavno ravnateljstvo za zdravstvo, 48152-Z-1942 . 
pjelo kolonizirati, odnosno smjestiti u udomiteljske obitelji ili druge ustanove s manjim brojem djece. To je bio i najuspješniji način rješavanja brojnih klasičnih zaraznih bolesti koje su se vrlo lako širile u prihvatilištima. Ako je ponegdje i bilo određenih organizacijskih propusta (dr. Antun Najžar pisao je kako je u Sisku zbog nužnog smještaja u nedovršenim zgradama smrtnosti pridonijela i noćna hladnoća, a sporenja o načinu zbrinjavanja djece bilo je i u Domu na Josipovcu u Zagrebu), iz dostupnih dokumenata se jasno razabire da nije postojala namjera da se toj djeci naškodi na bilo koji način, odnosno da nisu bila izvrgnuta izgladnjivanju, nasilju ili trovanju. Uistinu, mnogoj od te djece spašen je život, ugrožen glađu i bolesti. Djeca su pripadala manjinskoj (srpskoj) etničkoj skupini u tadašnjoj državi čiji su mnogi pripadnici sudjelovali u pobuni protiv države. To zacijelo nije bio razlog zašto su dospjela u prihvatilišta, nego nastojanje da im se pomogne bez bilo kakve diskriminacije.

Iako se i u onodobnim izvješćima katkad navodi da su djeca zbrinjavana u logorima ${ }^{124}$, svi dostupni dokumenti ukazuju na to da je prije bila riječ o prihvatilištima, sabiralištima, domovima pa i privremenim bolnicama za djecu u Sisku i Jastrebarskom. Isto tako, primjerenije bi bilo koristiti termine prihvaćanje, zbrinjavanje, liječenje, skrb, odnosno udomljavanje djece, nego spašavanje (spašavanje sugerira da je djeci prijetila neposredna smrt od ubijanja ili namjernog ozljeđivanja). U analiziranom gradivu nema niti jednog dokaza, čak niti jedne izjave sudionika, odnosno svjedoka događaja u prihvatilištima koji bi ukazivali na fizičko nasilje nad djecom.

Igor Vukić, Ilija Kuzman

Some Insights into the Housing and Healthcare of Children from Kozara in Children's Shelters of 1942

After the offensive of the Croatian and German army in the area of the Kozara mountain in the summer of 1942, a refugee camp was created with a large number of starving and sick children. When the Partisan resistance was crushed, large groups of children from the camp were temporarily moved to a number of reception centres (concentration camp Stara Gradiška, shelters in the villages of Mlaka, Jablanac, Uštica, and elsewhere).

124 Dr. Dragišić je u ispitivanju pred Zemaljskom komisijom za ratne zločine 10. prosinca 1945., opisujući dom u Jastrebarskom, rekao da "ustaša za cijelo vrijeme u samome logoru nismo vidjeli, jer su svugdje na ulazu bile izlijepljene table 'zarazne bolesti' i 'pristup strogo zabranjen'. Spomenuo je da je samo jednom došao ustaški poručnik iz Karlovca koji je rekao da ima zadatak popisati djecu i nadzirati logor. No prestao je i on dolaziti u bolnicu, tako da stvarno tamo nije bilo straže, rekao je Dragišić Vidi Ćiril PETEŠIĆ, n. dj., 101. 
Then, without prior preparations, they were all moved to further temporary shelters with the goal of providing general care and healthcare. The children were later placed in foster homes. The organization of placing the children into any form of housing depended for the most part on the State. From available documents, it is clear that the children in the camps were given housing and food, as well as adequate healthcare, meaning that the children were not discriminated against or neglected. The basic purpose of this paper is to show that children from Kozara and Potkozarje in 1942 had adequate general care and healthcare, in accordance with the capacities of medicine at the time in the given circumstances of war. This is done by using original archive materials and statements of participants of the events (court records).

We wrote this paper because today there is an abundance of opinions in various media that the children were starved, poisoned, and tortured. Here we want to point out that these claims are arbitrary and unfounded, spread by the Yugoslav communist regime after the end of World War II, as well as certain social, political, and even scientific groups. Therefore, the terms "children's camps" or "Ustasha camps" are inappropriate, and instead, the terms "reception centres" or "children's shelters", even "children's hospitals" should be used.

Key words: World War II, Independent State of Croatia, Children's Shelter Jastrebarsko, Children's Shelter Sisak, Institute for the Education of Deaf-Mute Children, Children's Home at Josipovac, infectious diseases 